\title{
Lapita Writ Small? Revisiting the Austronesian Colonisation of the Papuan South Coast
}

\author{
Glenn R. Summerhayes ${ }^{1}$ and Jim Allen $^{2}$ \\ 1 Department of Anthropology \\ University of Otago, Dunedin \\ New Zealand \\ glenn.summerhayes@stonebow.otago.ac.nz \\ 2 Department of Archaeology \\ La Trobe University \\ Bundoora, Australia \\ jjallen8@bigpond.net.au
}

There may be something to be gained by comparing different episodes of colonisation with one another to see what they have in common as processes (Irwin 1991:506).

\section{Introduction}

By the late 1970s the prehistoric sequence of the Papuan coast was perhaps the best known in Melanesia. This was a product of the establishment in 1969 of archaeology at the University of Papua New Guinea and a succession of doctoral theses from the Australian National University (ANU). By this time data informing this sequence were known from excavations right along the south Papuan coast and Massim area (see Figure 1 and Table 1).

A subsequent shift of interest at the ANU to island Melanesia and the parallel growth of Lapita studies has seen the archaeology of mainland Papua languish, with only a couple of research investigations resulting in one major published study (Frankel and Rhoads 1994) and associated articles on Papuan Gulf research (Frankel and Vanderwal 1982a, 1982b, 1985; Rhoads 1982; Rhoads and MacKenzie 1991) together with some lesser enquiries around Port Moresby (Bickler 1997, 1999a). However, in the Massim more recent research by Irwin (1983, 1991), Bickler (1999b, 2006; Bickler et al. 1997), Burenhult (2002) and Kewibu (pers comm.) has extended what might loosely be called the South Papuan Province into these islands.

Much of the significance of these early pieces of research is now diminished because they were written, if not in ignorance of Lapita, certainly in the absence of our vastly improved knowledge of Lapita and 


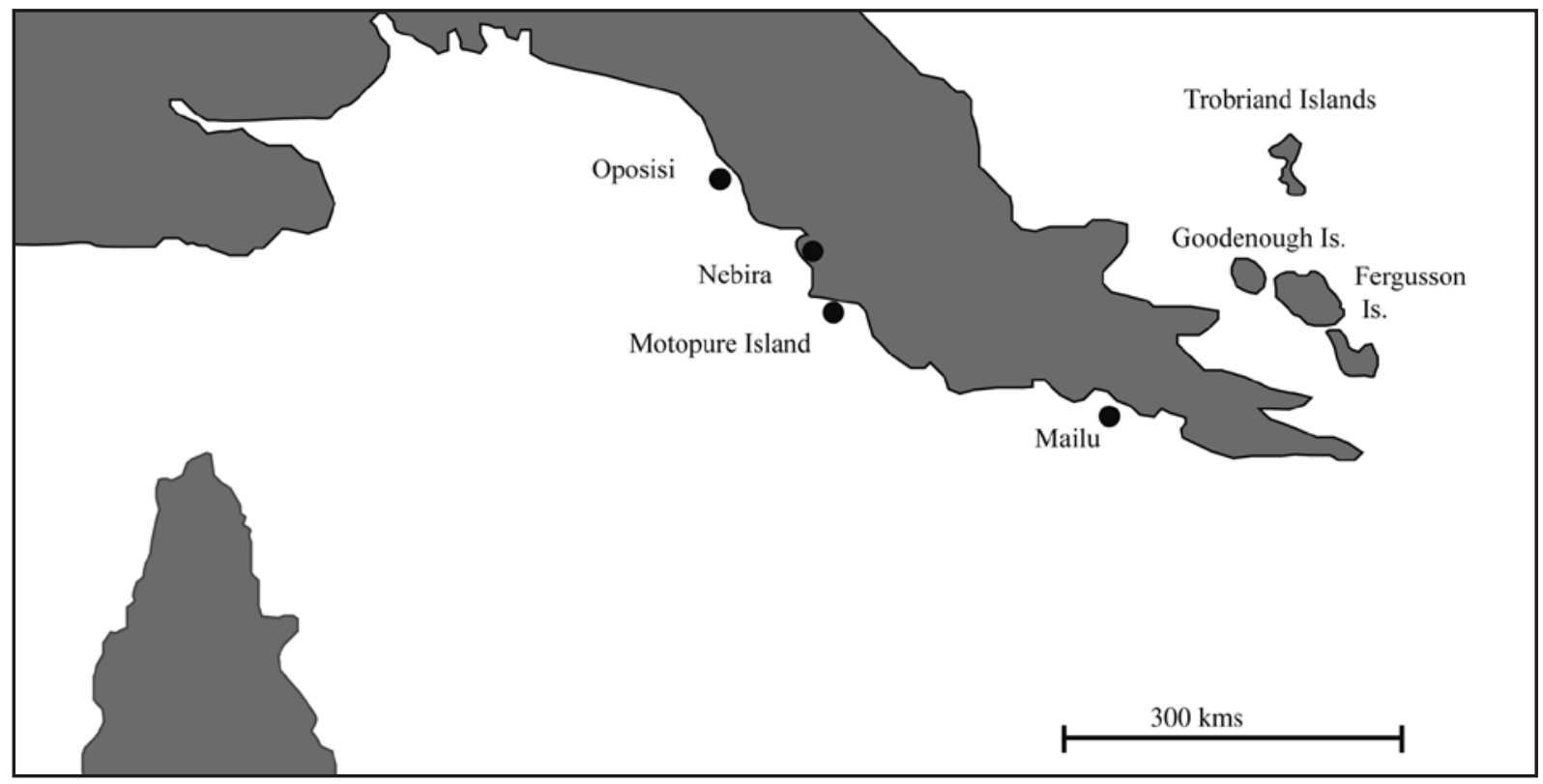

Figure 1. Map of the South Papuan Coast with sites.

post-Lapita archaeology in the Bismarcks and nearer Melanesian islands, and the specific research questions that now occupy researchers in those areas (for an update see Summerhayes in press a). Research into the Lapita assemblages from the Bismarck Archipelago has had a fundamental impact on the way the region's past is now modelled.

For example, early research into Lapita sites suggested that similarities in pottery were due to trade or exchange from a single or small number of production centres. Yet, research using chemical and petrographic techniques has now shown that pottery was mostly made locally. At the same time, we now recognise temporal changes to the production techniques for this pottery. Production during the Early Lapita period used many combinations clays and types of filler, while later Lapita assemblages indicated local production using only one clay associated with one filler in any particular area. Summerhayes $(2000 a, 2000 b, 2003)$ used this analysis of pot production to argue for a change from a mobile society to a more sedentary one, with the long distance exchange of pottery in the Bismarck Archipelago occurring after Lapita pottery had disappeared. Models of this sophistication were not available to inform early syntheses of south coast Papuan prehistory, although Irwin's (1977) doctorate on the emergence of Mailu as a specialised pottery manufacturing village was seminal in offering moves away from earlier culture history approaches.

We consider it worthwhile to revisit the south coast data for two reasons. The first is to examine the degree to which the colonisation of the Papuan coast is similar to or different from the Lapita colonisation, despite differences of scale. Although the Papuan diaspora involved pot-making Austronesian speakers, themselves ultimately Lapita descendants, an important difference between the two colonisations is that in Papua, people colonised a continental size landmass, something that Lapita itself seems not to have achieved, whether or not it was attempted. The only suggestions of Lapita-like connections with mainland Papua New Guinea are based on tenuous links. There is a Lapita sherd reputedly collected by Leask from the Aitape area of the New Guinea north coast, that has yet to be chemically provenanced; a weathered sherd from Ali Island thought to be dentate stamped (Terrell and Welsch 1997); and from the Wanigela area of Collingwood Bay, cut-out pedestaled bowls reported by Egloff $(1971 a, 1979)$ in undated situations are seen by Kirch (2000:122) to possess a "striking Lapita affinity". These finds, together with the single piece of Fergusson Island obsidian recovered from a Lapita site in the Solomons' Reef-Santa Cruz Islands (Green and Bird 1989), does not rule out the future discovery of 
Lapita on the Papuan mainland and in the Massim. On the other hand, given the now extensive work in the Massim, it seems improbable that Lapita sites have been missed, given their high visibility elsewhere.

The second reason is that in many Pacific areas it is difficult to choose between two models of postLapita change, one being localisation and adaptation and the other being cultural replacement. The occupation of the south coast by pottery users is considered by all researchers there to represent cultural replacement. Thus the question emerges, can the Papuan example inform post-Lapita studies elsewhere in Melanesia?

$$
\text { Following Irwin's }
$$

directive, this paper draws attention to the similarities between the Lapita colonisation and the colonisation of the Papuan coast by pottery-using communities. Irwin (1991) himself pointed to this comparison without emphasising it and also listed most of the colonising characteristics we also discuss here. This paper is designed to continue that dialogue.
Table 1. Excavations along the south Papuan Coast and Massim Area prior to the 1980s.

\begin{tabular}{|c|c|}
\hline Site & Reference \\
\hline \multicolumn{2}{|l|}{ Gulf } \\
\hline Rupo & Rhoads 1980 \\
\hline Kulupuari & Rhoads 1980 \\
\hline Samoa & Bowdler's work not published \\
\hline Samoa & Rhoads 1980 \\
\hline \multicolumn{2}{|l|}{ Kairuku Region } \\
\hline Kukubu Cave & White, J.P. 1965 \\
\hline Kukubu Cave & Vanderwal 1973 \\
\hline Oposisi & Vanderwal 1973 \\
\hline Ape Venuna & Vanderwal 1973 \\
\hline Urourina & Vanderwal 1973 \\
\hline \multicolumn{2}{|l|}{ Port Moresby } \\
\hline Nebira 2 & Bulmer 1971, 1978, 1979 \\
\hline Taurama & Bulmer 1971, 1978, 1979 \\
\hline Eriama & Bulmer 1971, 1978, 1979 \\
\hline \multicolumn{2}{|l|}{ Motupore } \\
\hline Nebira 4 & Allen 1972 \\
\hline Ava Garau (nеar Воега) & Swadling 1980, 1981 \\
\hline Papa Salt Pan & Swadling and Kaiku 1980 \\
\hline \multicolumn{2}{|l|}{ Amazon Bay } \\
\hline Mailu Is. 01 and 03 & Irwin 1974, 1977, 1978a and b \\
\hline \multicolumn{2}{|l|}{ Selai } \\
\hline \multicolumn{2}{|l|}{ Collingwood Bay } \\
\hline Wanigela Area & Egloff 1971a and b, 1978, 1979 \\
\hline \multicolumn{2}{|l|}{ Goodenough Island } \\
\hline Nuamata & Egloff 1978 \\
\hline Surface Goodenough, Amphletts & Lauer 1970, 1971, 1974 \\
\hline \multicolumn{2}{|l|}{ Trobriands } \\
\hline Kiriwina, Kaileuna, Kitava, Vakuta & Egloff 1978, 1979 \\
\hline
\end{tabular}

\section{The South Coast sequence}

Sites older than 2,000 years are few along the south Papuan and Papuan Gulf coasts. Two examples from the Gulf are Ouloubomoto and Rupo from the Kikori region (Rhoads 1980). To the east of these it is remarkable that only a single pre-ceramic site has so far been recognised, at Kukuba Cave (ADL) near Yule Island, where a flaked stone assemblage yielded a mid-Holocene date (Vanderwal 1973:44-47, 51). This dearth of evidence is less likely to reflect a landscape empty of humans and more the difficulties of finding these earlier sites. But for the moment we have no idea

Table 2. The South Coast Sequence.

\begin{tabular}{ll}
\hline 1. & Pre-ceramic ? -2,000 BP \\
\hline 2. & Colonisation $2,000-1,600 \mathrm{BP}$ \\
\hline 3. & Regional Isolation $1,600-1,000 \mathrm{BP}$ \\
\hline 4. & Pottery Transformation $1200-800 \mathrm{BP}$ \\
\hline 5. & Interaction, Specialisation and Exchange $800-200 \mathrm{BP}$ \\
\hline
\end{tabular}


what sort of cultural landscape the earliest pottery-bearing colonists encountered. The remainder of the regional sequence (Table 2) presented above was proposed by Irwin in 1991 and is used here to overcome the earlier confusion of local geographical and decorative style names given by various researchers to their own sites and regions.

Before reviewing Irwin's regional sequence we note that almost universally, early researchers divided the ceramic sequences into a more recent phase, where pots although prehistoric, have generic associations with local ethnographic wares, and an earlier phase where different generic relationships were observed archaeologically between regions. As a radiocarbon chronology was developed, local sequence disruptions were recognised at various sites along the coast somewhere between 800 and 1200 years ago that separated these earlier and later phases. This general disruption, dubbed the "ceramic hiccup" by Irwin (1991), appears to have carried beyond ceramic style changes, invoking socio-economic system changes along the entire coast.

Within this gross Early/Late dichotomy, pottery associated with the earlier phase has been given many labels. At first widely known as Red Slip pottery, this term was rejected because much of the pottery in this tradition is not slipped (Allen 1972). It has also been called the Laloki style (Bulmer 1999), the Initial Ceramic Phase (Vanderwal 1973:232, 1978:426), Early Period (Allen 1977a and b; Bickler 1997), Early Papuan Ware (Irwin 1991:503), and, jokingly, SPECHT ware (South Papuan Early Ceramic Horizon or Tradition). We now prefer and use the term Early Papuan pottery (EPP). While early researchers analysed pot shapes and rim forms of EPP and found changes through time (Allen 1972), decorative techniques and motif analyses have been most informative and these are what we concentrate on here.

\section{Irwin's Regional Sequence (Irwin 1991)}

Period 1 represents the sketchy pre-ceramic occupation down to c.2000 BP. Around this time or a little later, a number of sites, spread over $500 \mathrm{~km}$ of the south Papuan coast, were occupied for the first time by people using an identical style of pottery (Bulmer 1999:543). Period 2, representing this colonisation phase, is primarily defined from three major locations: Mailu Island's O1 and O3, and the site of Selai (Layer D) on the opposing mainland (Irwin 1977, 1985), Nebira 4 (Horizon III) near Port Moresby (Allen 1972), and Oposisi on Yule Island (Vandewal 1973, 1978) (see Figure 1). Early pottery was also found at Taurama (AJA) (Bulmer 1978), but the site may be disturbed (White with O'Connell 1982:201-2).

At all locations where the stratigraphy is intact, the earliest decorative form is elaborate shell impression (see Allen 1972: Fig. 7; Vanderwal 1978:420), lime infilled, mostly on bowls and found in all zones of the exterior surface. This is consistent from the Massim to the Gulf of Papua. The bowls without shell impression are either plain or have a single groove round the outside of the rim. Other vessel forms include small orifice vessels which Vanderwal (1978:418) called water jars, some with red paint, and the cooking pot which is larger with a wide flat rim. These forms are also found at Nebira 4 (Allen 1972), Taurama (Bulmer 1999) and Mailu (Irwin 1977) at least for cooking pots. As this implies there was some variation, such as the lack of rim grooving at Nebira that was dominant at Oposisi, and the absence of globular water pots at Mailu (see Bulmer 1999 for a review of the pottery). Multiple body grooving below the rim was also found on shell impressed bowls at Nebira 4 and in the Mailu assemblages. (Such grooving is also found in the Lapita assemblages of the Arawes (Summerhayes 2000a)). As discussed below this period was also associated with a wide range of non-ceramic material culture, particularly at Oposisi.

Periods 2 and 3 are separated by Irwin to accommodate a division between a period of initial colonisation where the same ceramics are found from the Massim to the Gulf and the first indication of regional variation in pottery styles. Examples of the latter are seen at Mailu where some local motifs develop and other 
more widely distributed motifs like multiple grooving and painting continue, and at Port Moresby and Yule Island, where a similar series of parallel styles continue in both places down to about $1200 \mathrm{BP}$.

Contact between Mailu and localities further west is difficult to judge because Irwin did not report in detail any temporal sequencing of styles within the EPP tradition at Mailu, however this parallel sequence of styles at Nebira 4 in Port Moresby and Oposisi on Yule Island was quickly recognised. Shell impression in both regions in turn gave way to finely incised wares, again frequently lime-infilled (see Allen 1972: Figure 7 nos. 1-17), then multiple grooving (Allen 1972: Figure 6 nos. 9, 12) and finally etched decoration (Allen 1972: Figure 6 nos. 1-7) where the slip is scraped off prior to firing. Painted wares, present in the Port Moresby and Mailu sites and occurring throughout the Nebira 4 sequence, are absent in the Yule Island area. Conversely, etching, the most recent EPP style in the Port Moresby and Yule Island sites does not occur at Mailu. For a full description of the decoration see the original reports (Allen 1972; Irwin 1977, 1985; Vanderwal 1973, 1978).

Period 4 occupies the period between $1200 \mathrm{BP}$ and $800 \mathrm{BP}$ in which socio-economic systems and accompanying ceramic styles "transformed" in Irwin's terms from the earlier period to the later period as described above. Whereas the sudden appearance of pottery making communities a thousand years earlier is seen universally as a migration/ colonisation, this transformation, initially argued by some to represent another migration event, is now seen to be a set of separate local reorganisations that were different from each other but likely to be causally related because of their contemporaneity. We return to this point in the discussion. In each region the record differs; in Mailu Irwin noted continuity in settlement patterns and other non-ceramic data; in Port Moresby Bulmer (1971) thought new pottery styles indicated external introductions from the Massim, a view she later retracted (Bulmer 1978). In the Port Moresby and Yule Island regions settlement patterns changed. At the peripheries changes occurred that were different again. In the Gulf pottery sites disappeared for a time, while in the Louisiade Archipelago "antique" EPP continued to be made for several more centuries (Irwin 1991:507-508).

As stated, all researchers accept that EPP, whatever the local sub-style forms, was abruptly replaced between $1200 \mathrm{BP}$ and $800 \mathrm{BP}$. Taking a line through several western Port Moresby sites dug by Pam Swadling and colleagues (1977, n.d.; Swadling and Kaiku 1980) we now put the start of this disruption very close to 1200 BP, at least for the Port Moresby area. Elsewhere the dating is less precise and the sequences at the major sites now warrant re-dating. Change and reorganisation over the next 400 years led to the subsequent emergence of the immediate antecedent systems of specialised exchange seen in the ethnographically described Kula, Mailu and the Port Moresby Hiri systems. These occupy Period 5 in the Irwin scheme.

The rest of this paper concentrates on the Period 2 phase of colonisation and structural similarities with the Lapita colonisation of the Bismarck Archipelago and the Western Pacific.

\section{Period 2 Phase - Colonisation of the south coast - the Argument}

Any similarity between the dynamics of the original Lapita colonisation and the subsequent colonisation of the south Papuan coast by pottery-users could reflect some of the shared processes of colonisation that Irwin urges us to seek. Here we look at six of these: speed of colonisation, site location, economy, obsidian, other material culture, and pottery, with the latter two being indicators of connectedness. The first five will be looked at briefly, the last in more detail.

\section{Speed of colonisation}


No one working in the region doubts that the appearance of pottery-users along the south coast reflects a sea-borne migration of deliberate colonists, which is also the dominant model for Lapita. While some researchers (Kirch 2000) have argued for a westto-east temporal cline in Lapita colonisation of the Bismarck Archipelago the distinctions may reflect the vagaries of radiometric dating as much as reality. Summerhayes has recently argued that the Lapita colonisation of the Bismarck Archipelago was instantaneous, with differences in dating due to the different calculation of oceanic reservoir effects used on shell samples
Table 3. Radiocarbon dates from earliest pottery occupation levels of the south Papuan Coast.

\begin{tabular}{|c|c|c|}
\hline Site & Radiocarbon date & Reference \\
\hline \multicolumn{3}{|c|}{ Mailu Area } \\
\hline Mailu 01 & $1900 \pm 70$ BP (ANU-1229) & Irwin 1988:66 \\
\hline Selai & $1790 \pm 70$ BP (ANU-1316) & Irwin 1977:82 \\
\hline \multicolumn{3}{|c|}{ Port Moresby Area } \\
\hline Nebira 4 & $1760 \pm 90$ BP $(\mathrm{I}-5796)$ & Allen 1972:99 \\
\hline Eriama & $1930 \pm 230(\mathrm{GaK}-2670)$ & Bulmer 1978:213 \\
\hline \multicolumn{3}{|c|}{ Yule Island } \\
\hline \multirow[t]{3}{*}{ Oposisi } & 1890_305 BP (ANU-425) & Vanderwal 1973:48 \\
\hline & $1530 \pm 160$ BP (ANU-729) & \\
\hline & $1600 \pm 210$ BP (ANU-728) & \\
\hline \multicolumn{3}{|l|}{ Gulf } \\
\hline \multirow[t]{2}{*}{ Samoa } & $1850 \pm 95$ BP (I-6153) & Rhoads 1980:250 \\
\hline & $2430 \pm 370 \mathrm{BP}(\mathrm{ANU}-2061 \mathrm{~A})$ & \\
\hline
\end{tabular}

(Summerhayes in press a). Available dates in Papua (Table 3) show this event also to be archaeologically instantaneous, likely occurring somewhere short of 2,000 years ago. Allen's (1972:109) Horizon III at Nebira correlates with Vanderwal's (1973) Style Ilb and IIc, and Irwin's Early Papuan ware (Irwin 1977). Re-dating all these sites using more modern techniques might pinpoint the colonising period more accurately, especially given the presence of "red slip" pottery in Torres Strait argued to be 2,500 years old (McNiven et al. 2006). However, despite earlier opinions such as Pawley (1969:3), who suggested on linguistic grounds that Austronesians might have been present on this coast 3,000 years ago, the existing radiocarbon ages are sufficiently similar to put the age of the pottery in Torres Strait in doubt if it reached Torres Strait via Papua, rather than from somewhere to the west.

The ease with which both the Lapita and the Papuan colonisations were achieved has tended to render prior occupants archaeologically invisible. In the case of Lapita in the Bismarcks, sheer persistence by a few workers has forced some recognition of this problem (Specht 2005; Torrence et al. 2004). Equally, on the south coast it would be foolish to believe these colonists encountered empty landscapes. Within the Bismarck Archipelago, Summerhayes (in press a) has argued that the population levels for the existing mobile hunting and gathering communities was low and the absence of evidence for earlier hunters on the Papuan coast suggests that the same is true there. In neither case has much attention been paid to the probable interactions between incumbents and new arrivals in these situations (e.g. Kirch 2000:93).

\section{Site Locations}

Lapita site locations are predominantly coastal, with most being beach locations (Anderson et al. 2001). The EPP sites are also mostly coastal. Oposisi is located on Yule Island on the highest part of the island at 125 metres a.s.l. (Vanderwal 1973, 1978:417) (Figure 2). Mailu is a small island, while Selai is a beach location (Figure 3; Irwin 1977). In the Port Moresby region EPP sites occur on beaches and headlands such as Taurama beach and headland and on islands, such as Daugo Island. Nebira on the other hand is 15 kilometres inland 
from the present coast. Nebira 4 is located at the northern base of Nebira Hill, a twin peaked hill rising c. $180 \mathrm{~m}$ from the flat Waigani plain (Figure 4). Nebira 2, excavated by Bulmer (1978), was located in the saddle of the two hills. Allen (1972) pointed out that although the areas is now savannah woodland, it need not have been in the past, since the sea may have been much closer than it is today. The higher sea stand of 1.5 metres at $3300 \mathrm{BP}$ would have covered nearby low lying areas, likely locating Nebira Hill much closer to the sea than it is now. The subsequent infilling of this area is also to be expected, given that Swadling et al. (1976:56) point out that the Papuan Coast has prograded with the Angabanga plains being produced by Holocene age alluvial and littoral deposits. Roro traditions note that the Hall Sound area once had islands and Redscar Head, which is today joined to the mainland by a mangrove swamp, was recorded by the Spaniard Don Diego de Prado in 1606 as being an island (Swadling et al. 1976:56). More detailed geomorphological work

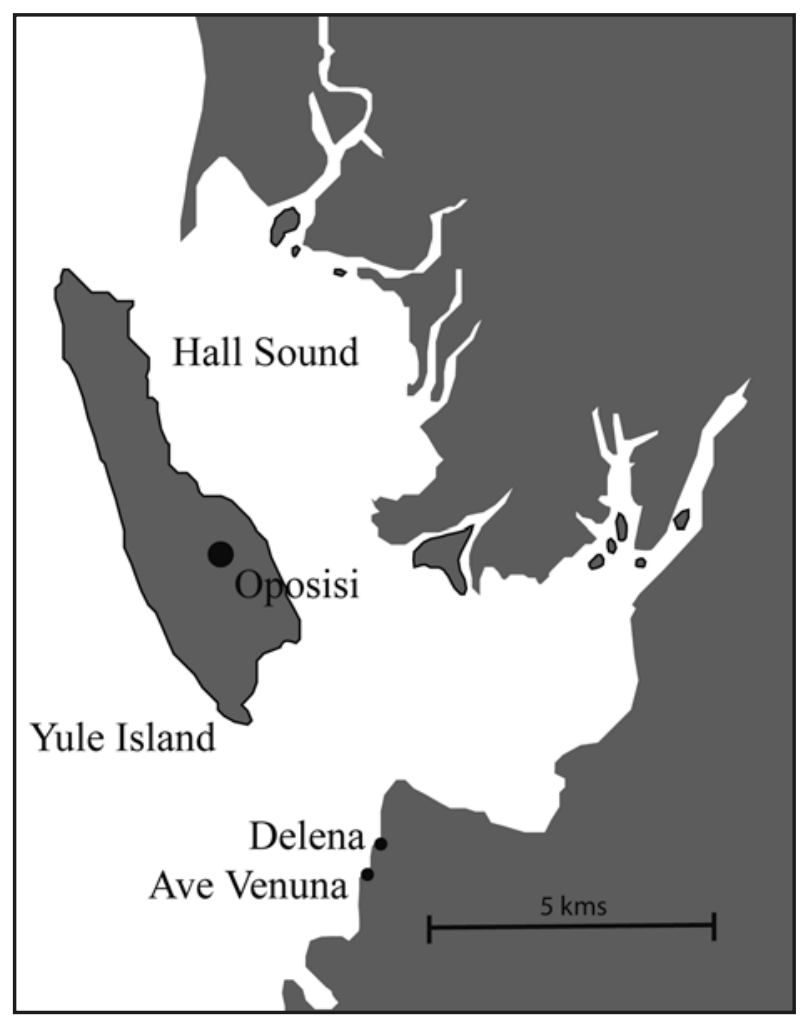

Figure 2. Location of Oposisi and surrounding sites (from Vanderwal 1978). in the region is needed.

In summary, site locations reflect the sea-borne nature of the Papuan colonisation, with village sites occurring on larger and smaller offshore islands, beaches and headlands, but with inroads into coastal hills and river valleys occurring quickly. While these last locations probably reflect the utilisation of better gardening land, pottery is also found in caves and rockshelters (e.g. Eriama, Kukubu Cave). Is this reflecting

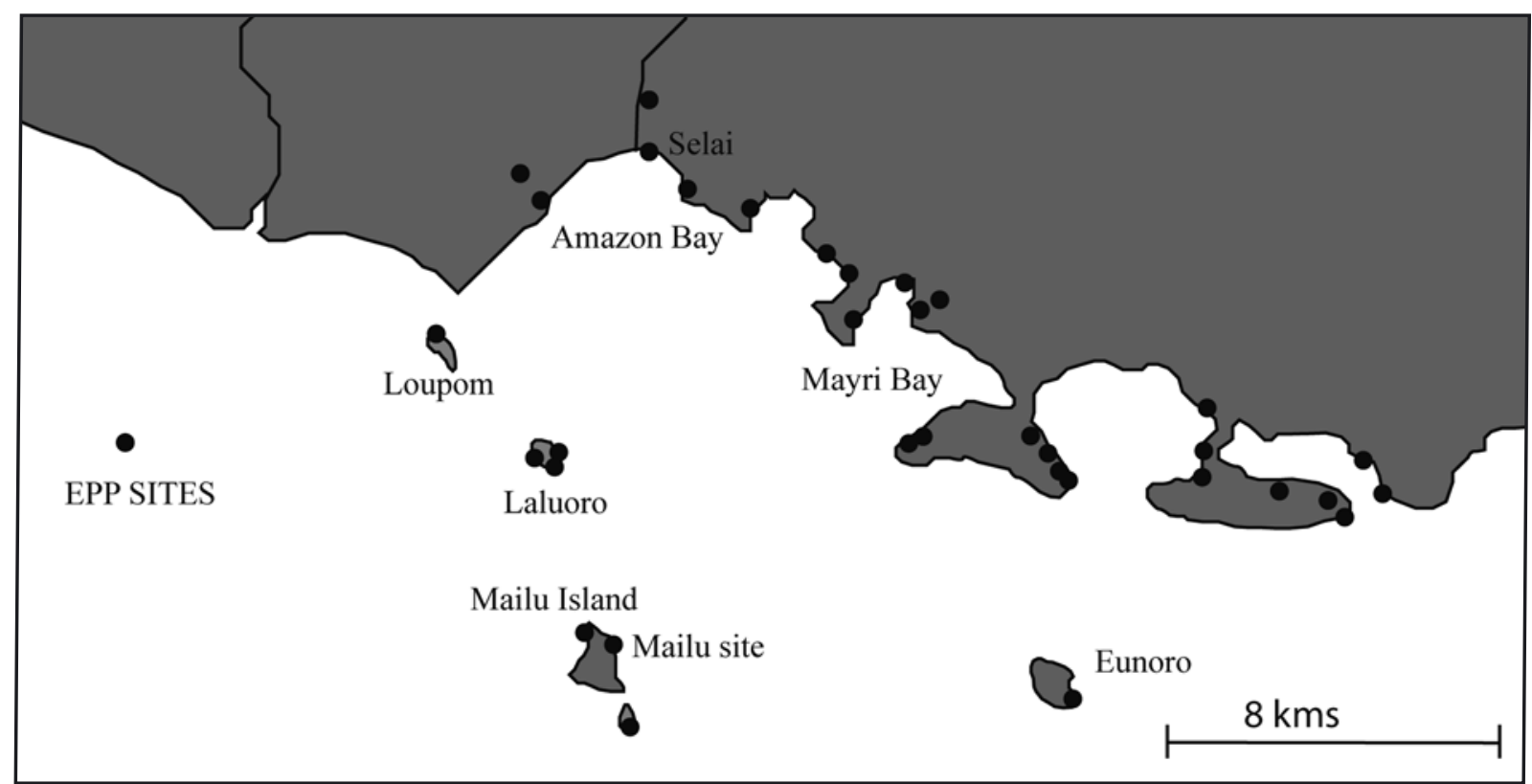

Figure 3. Location of EPP sites and findspots recorded by Irwin on Mailu Island and surrounding areas (Irwin 1985 Table 17). 


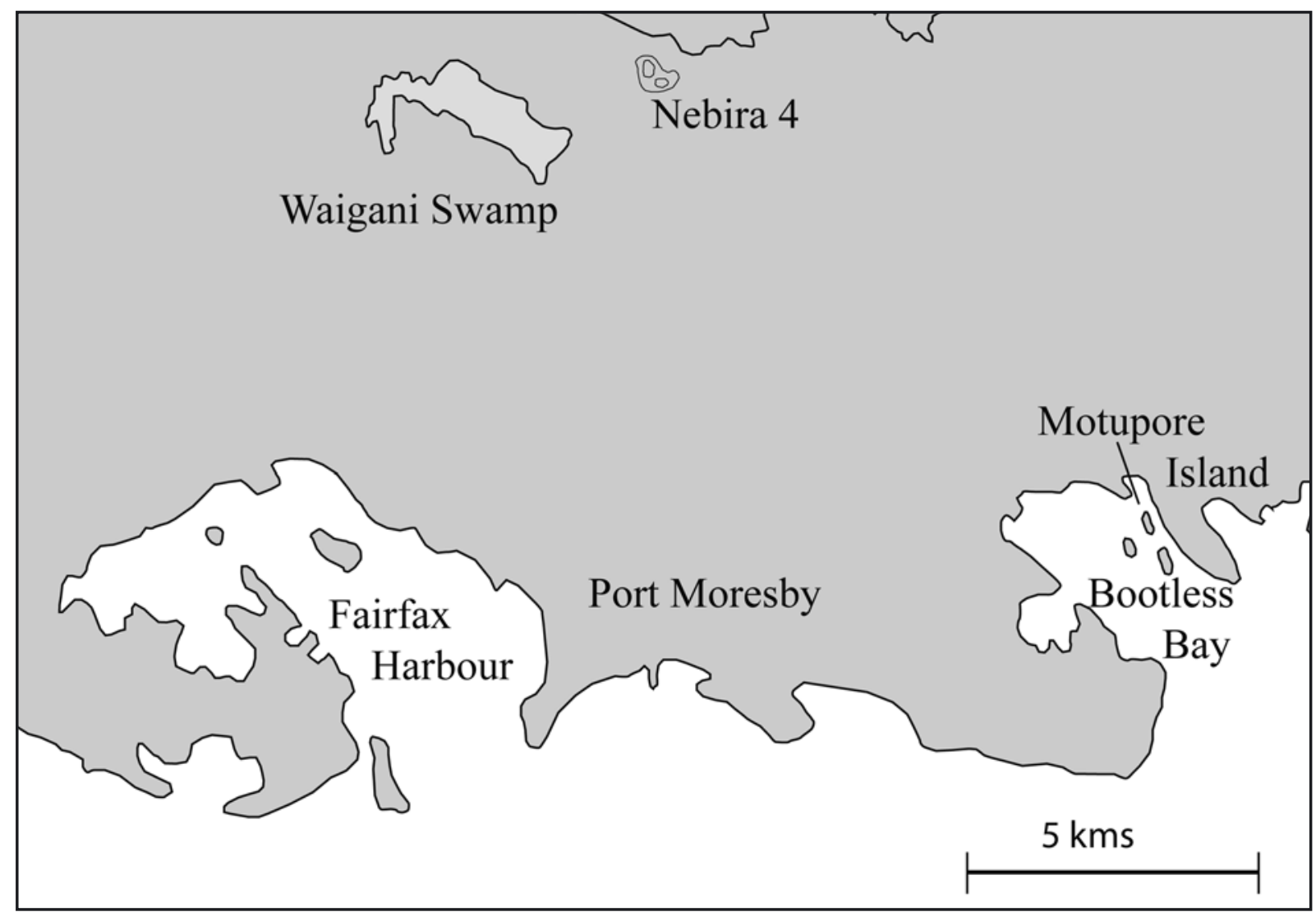

Figure 4. Location of Nebira (from Allen 1972).

the broad spectrum subsistence activities of the colonists or the transfer of pottery to prior occupants through exchange? Certainly in some Lapita situations where there are no prior occupants, it represents the former. On the Papuan coast we simply need more data to investigate this question.

\section{Economy}

The economies of both Lapita and Papuan sites appear to be mixed, with strong emphasis on marine resources (fishing and collecting) supplemented by hunted and gathered land resources and with the continuing inference of horticulture. Nebira's inland location is of interest in this respect since the faunal material from the early phase at Nebira 4 reflects a strong marine imput that diminished over time (Allen 1972:116). Apart from catfish (Tachysuridae), the rest of the fish found at Nebira 4 were coastal reef dwellers (Aluteridae or Balistidae, Scaridae and Labridae). Turtle and dugong were also found in the earliest levels, as were thirty-six species of marine molluscs. Less than $1 \%$ of molluscs were fresh water species (Melania sp and Velesuni sp). The most common marine shell species among the 36 species identified were Chama sp., and various strombus species (S. labiatus, S. luhuanus, S. gibberulus gibbosus and S. canarium). Of importance is the presence of Chama sp. At Nebira Allen mused over its presence, as the shell has a high shell/meat ratio (Allen 1972:119). Why carry it so far inland? The answer may well lay in the geomorphological changes that have occurred over the last 2,000 years, and may provide support for Nebira being closer to the sea at its initial occupation. Evidence for local hunting was seen in the presence of wallaby (M. agilis) and horticulture in the presence of pig. 
The economy of the earliest layers at Oposisi was similar, providing evidence that both land and sea were exploited for subsistence. Shellfish remains were found in large quantities, along with wallaby, fish, turtle, dugong, crocodile, cassowary and pig (Vanderwal 1973:178, Table VII-23)

The economy of Mailu in the early pottery period was coastal (see Irwin 1985: Chapter X). Midden material was mostly shell fish, with species of shell reflecting the ecological differences between Mailu and mainland sites. Turtle, dugong, fish, crabs and sea urchins are also found. Shellfish, however, was found in great volume. Vertebrate remains were in Irwin's terms meagre (1985:241). Pig and dog were found, along with two types of wallaby (M. agilis, Dorcopsis sp.) which must have derived from the mainland (Irwin 1985:237).

Like the Papuan assemblages, the coastal location of Lapita settlement was reflected in the economy. From the Early Lapita site of Kamgot (on Anir) for instance, fish bone dominates the faunal assemblage. The most popular fish were inshore varieties such as Scaridae and Diontidae. Most of the fishing was inshore or from the reef, although shark, tuna, dolphin, turtle and barracuda were also present. As expected with some of these species a number of fishhooks were recovered from Anir (Szabo and Summerhayes 2002). A similar exploitation of fish occurs at another Early Lapita site, Mussau, as well as the later Lapita site of Watom (Butler 1988; Green and Anson 2000:52; Kirch et al. 1991). Fishhooks are also found at these sites. From Kamgot, the midden remains also have a high land mammal content, including phalanger, Thylogale browni, pig, chicken, dog, and Rattus exulans. Found in association with house structures, pig, chicken and dog are domesticated, and as such, are also good indicators of horticulture. There is also evidence for arboriculture from the Early Lapita assemblages at Mussau and the Arawe Islands (Kirch 1989; Matthews and Gosden 1997).

From later Lapita assemblages the diet was mostly terrestrial. At Watom for instance it was argued on the basis of stable isotope analysis on human bone that $64 \%$ of the diet was land based, the rest made up of shellfish (8.7\%), coral reef fish (9\%) and non-reef fish (21.3\%) (Green and Anson 2000:51). Plant foods made up most of the food energy (Leach et al. 2000:158). Large numbers of pig bones were also found at Watom enabling a detailed study on age distribution that suggests animal husbandry (Smith 2000:145). Green and Anson argue that this is indirect evidence for agriculture necessitating "domesticated plant foods in sufficient abundance to feed both pigs and people" (Green and Anson 2000:50).

Independent evidence for Lapita agriculture using either starch residue analysis on pottery and/ or phytolith analysis on sediments is now provided from the following Lapita sites: Kamgot (Crowther 2005); Uripiv Island, Vanuatu (Horrocks and Bedford 2005) and Bourewa, Fiji (Horrocks and Nunn 2007) where Colocasia esculenta has been identified. Palms and banana (Eumusa) have also been identified from Watom (Lentfer and Green 2004). Unfortunately, these newer scientific techniques have not yet been applied to the pottery and deposits from the south coast.

It is hardly legitimate to list a mixed economy of fishing, collecting, horticulture and hunting as a distinctive marker, since these may well have occurred before the colonisations and certainly after. But for the first time in both the Bismarcks and the Papuan coast an increased intensity of subsistence acquisition in the archaeological record is sufficient to equate it with the first appearance of open village sites (although these may have already been present in the Bismarcks (Allen 2000:156-163)). While it is acknowledged that the high visibility of sherds in tropical landscapes might explain an increase in recognised sites, it is not sufficient to explain this sudden increased visibility. Sites are occupied by more people for longer periods.

\section{Obsidian}

All or most models of Lapita emphasise connections between sites and sometimes back to homeland regions. These linkages continue through time but are most visible and elaborate in the early phases of the colonising 
process (Kirch 1988; Summerhayes 2000a). Archaeologically this connectedness is marked by similar pottery styles and the distribution of obsidian and these are clearly parallelled in the Papuan case.

Obsidian, all sourced from Kukuia and Fagalulu, west Fergusson Island, has been reported from a number of EPP sites as far west as Yule Island but not in the Gulf (Ambrose 1976; Bird et al. 1981; Green and Bird 1989; Irwin 1991:Fig. 3). The amount of Fergusson obsidian reaching these sites reflects the distance from the source (Irwin 1991: Fig. 3; White et al. 2006). In the Oposisi assemblage, two Kukuia flakes were found, more than $650 \mathrm{~km}$ from the source area (Vanderwal 1973:214). Two others came from nearby Apere Venuua (Vanderwal 1973:214). From Nebira, which is $550 \mathrm{~km}$ from the source, small quantities of flakes were found from the earliest levels to the most recent. From Mailu, which is 350 kilometres from the source, obsidian was found in larger quantities (146 for the early period), however, this decreases over time to only a handful after $1600 \mathrm{BP}$, with numbers rising again in the second millennium AD (Irwin and Holdaway 1996). However while obsidian again reaches Mailu in significant numbers at the beginning of the post-EPP phase, it does not get as far west as Port Moresby. Obsidian was still traded to Mailu up to the beginning of the twentieth century (Green and Bird 1989).

As modelled by Irwin (1991), the distribution of obsidian is what might be expected by down-the-line exchange, with much more appearing in Mailu sites, nearer to the source. While we believe the two pieces of obsidian reported at Oposisi are an underestimate resulting from the sieve mesh sizes used there $(1 / 2$ inch or $1 / 4$ inch used variably in the excavation (Vanderwal 1973:29), these general distinctions of volume between regions remain accurate. Sue Bulmer interpreted the small number of pieces in the Port Moresby sites as reflecting the unimportance of the trade in obsidian to Port Moresby (Bulmer 1979:23). Certainly the ready local availability of good quality chert reduced any utilitarian need for obsidian, and thus we see its small but continuing presence there as an important indicator of the maintenance of eastward linkages throughout the EPP phase, and not merely a reflection of the initial pulse of first colonisation. Yet, was the distribution of obsidian "down the line exchange"?

Changes in the nature of obsidian reaching Mailu inform us about the nature of interaction among these communities. The obsidian found in these early sites is technologically different from later assemblages suggesting different distribution processes. Technological studies on the obsidian assemblages from the Mailu region showed that the earlier "colonising phase" in Mailu had heavier obsidian than later periods, which is "incidental to the high frequency of communication among related communities undergoing a phase of expansion" (Irwin and Holdaway 1996:228). This is different to obsidian reaching Mailu during later periods in what Irwin called a later "trader mode" (Irwin 1991:506).

Similar processes are seen in the distribution of obsidian in the early Lapita assemblages. Earlier Lapita assemblages show an expedient technology not seen in the earlier pre-Lapita or later assemblages away from the source regions (Summerhayes 2004, in press b). Hanslip (2001:196) for instance argues that the earliest assemblages from the Reef Islands and Santa Cruz, RF-2 and SZ-8, which are also part of the colonising phase, not only had the largest pieces of obsidian and lacked bipolar flaking, but also showed no signs of onsite production. That is, the material was imported as is, not as blocks. Such an expedient technology is not expected from a down the line exchange network. Specht (2002:42) also shows that the earlier Lapita assemblages had heavier pieces of obsidian (mean weights) and from the one site where data is available (Adwe) there is a decline in this mean weight over time in the Middle Lapita period. Taken together the reduction in the size and weight of obsidian indicates an "economising" behaviour associated with later down the line exchange.

Yet, like the assemblages from Moresby, obsidian continues to be distributed after the initial colonisation pulse is over. Obsidian continues to be imported into Lapita assemblages in the Reef Islands and Santa Cruz well after it was initially colonised (Green 1987). East of the southeast Solomons obsidian is rare (although see Galipaud and Swete Kelly this volume) although still found in post colonisation contexts, such as in Naigini, Fiji (Best 1987), and Tikopia where it was found in Middle to Late Lapita contexts (Kirch and Yen 1982). Communication between these far-flung communities still existed after the colonisation phase in western Melanesia was over. 


\section{Non-ceramic material culture of the EPP phase}

The EPP phase contained a suite of artefacts beyond obsidian and pottery that is more reminiscent of the insular Pacific and Lapita sites than the post-EPP phase that eventually replaced it along the Papuan south coast. The best examples come from the Yule Island sites. Oposisi in particular produced an elaborate range of bone and shell artefacts, among them awls, scrapers and gouges, spatulas with handles, tubular bone beads, including some from human bone, human cranial tablets, pierced animal teeth and pendants, shell beads and conus and trochus bracelets. Vanderwal (1973:129-32) also described 26 adzes of which 16 were trapezoidal in form, different from the more common lenticular Papuan forms. These trapezoidal forms occurred mainly in the earliest stratigraphic unit of Oposisi (IIC) and at the nearby site of Apere Venuna, which Vanderwal equated with Oposisi IIC on ceramic grounds (Vanderwal 1973:131). Two similar adzes occurred in the surface collections from Nebira, but no other parallels are known within the EPP phase or subsequent to it along the Papuan coast. There are, however, 127 similar adzes in the Australian Museum in Sydney collected in 1934 by R. V. Oldham, and catalogued as coming from Delena, an existing town adjacent to Apere Venuna. This collection is thus considered to be a part of the Apere Venuna assemblage described by Vanderwal.

Most (but not all) of these artefact types occur only in the early part of the Oposisi sequence and are not seen in this abundance at other EPP sites, although aspects of this assemblage do occur at these other sites. Alone among Papuan researchers, Vanderwal considered that the more elaborately decorated shell impressed pottery and the associated rich bone and shell assemblages of the initial colonisers, when compared to the simpler material culture of later inhabitants at Oposisi, were sufficiently different to argue cultural replacement of the former by the latter. Today this view no longer holds, but the simplification of material culture that accompanied settling into the landscape raises other issues that we will return to in the conclusion.

\section{Pottery}

We have already touched upon connectedness reflected in similar sequencing of decoration styles between regions. Here we identify and compare pottery production patterns and changes over time between the south coast and Lapita assemblages in order to identify a pot production signature for colonising societies. This will be done by first outlining Lapita pottery production and its change over time; secondly by reviewing past attempts at identifying pottery production on the south coast using physical/chemical analyses; thirdly, presenting the results of our pottery production analyses using the electron microprobe; and lastly by comparing and contrasting the results of our analysis with Lapita pottery production patterns.

\section{Lapita Pottery Production}

Despite the amount of attention that has been given to Lapita pottery, relatively little has been done on identifying production and distribution patterns. With rare exceptions, most of the physical/chemical analyses of pottery have been limited to assessing whether pots have been locally made or imported. However, a study by one of us (GS) has attempted to tie production patterns to mobility/settlement models in Lapita settlements within the Bismarck Archipelago (Summerhayes 2000a, 2000b, 2003). Two patterns of production were identified.

The first suggests that production of Early Lapita pottery was mostly local. Technologically these potters were not conservative, using a number of combinations of tempers / fillers from different river systems and beaches and different clays to produce an identical variety of vessel forms and decorations (Figure 5). 


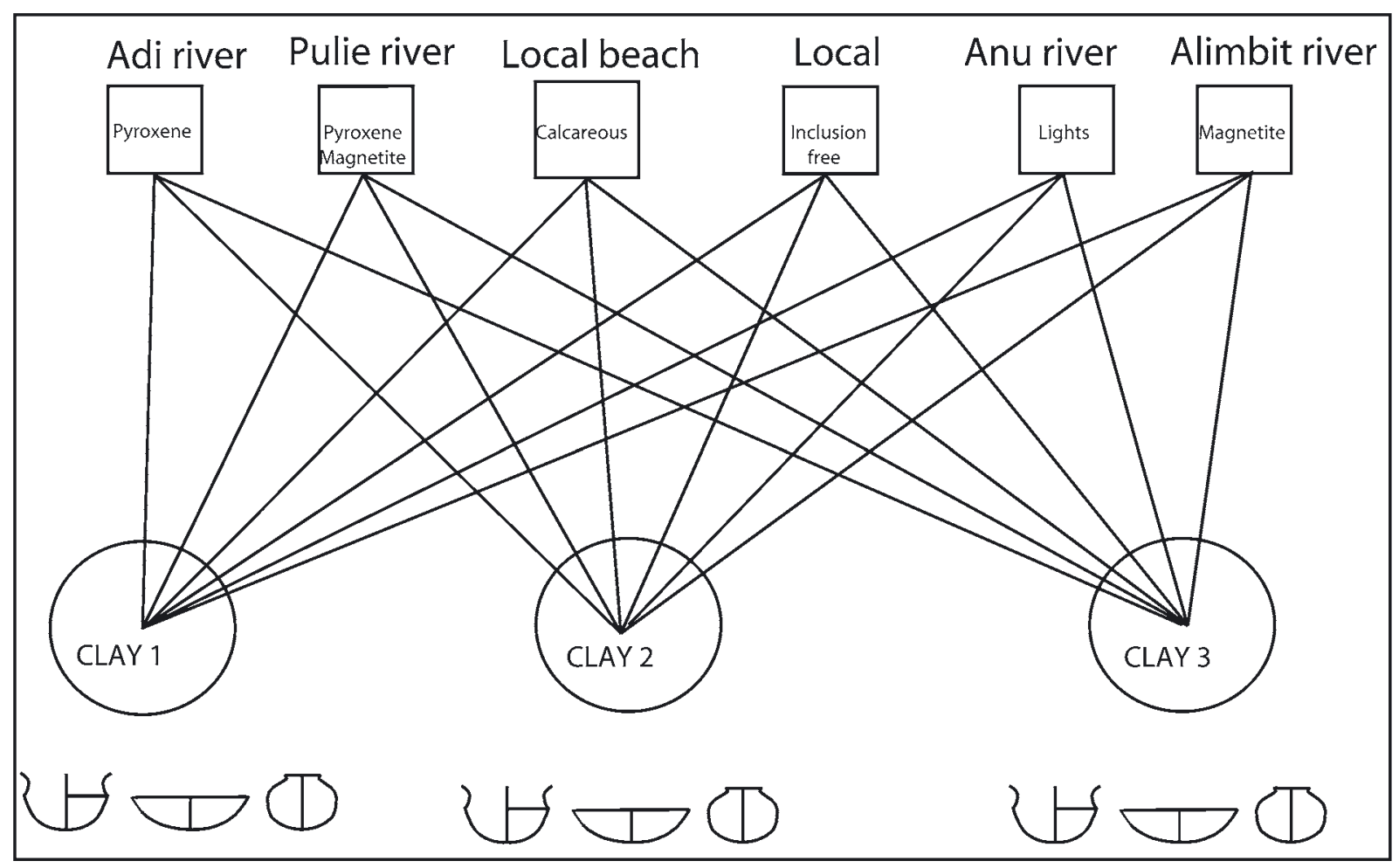

Figure 5. Early Lapita Production Pattern.

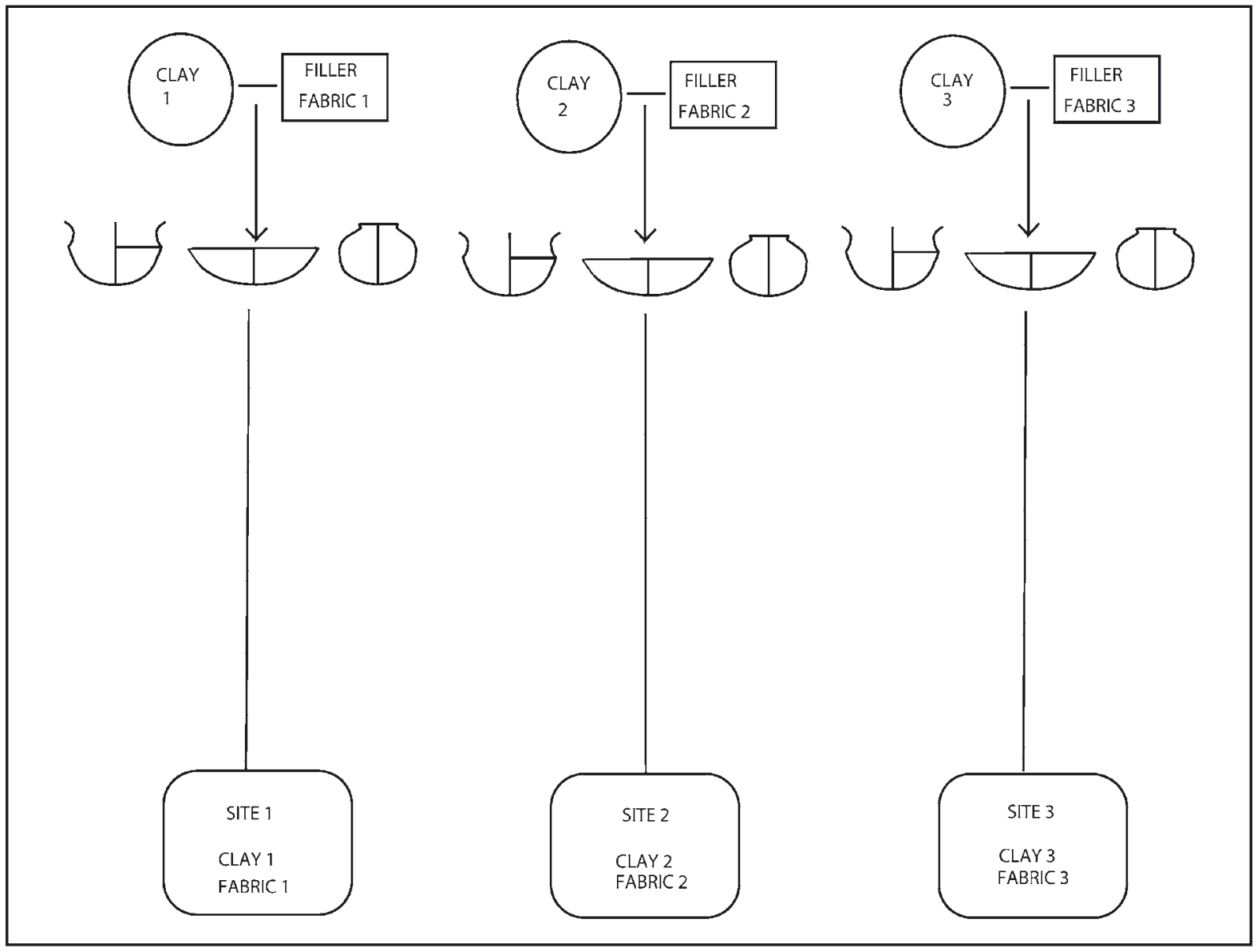

Figure 6. Late Lapita Production Pattern. 
A different pattern of production occurred for later Lapita styles. While production continued to be locally based, production became more conservative and standardised with only one temper/ filler found with associated clays (Figure 6).

This change in production was interpreted as reflecting a change in settlement patterns, with the early production pattern resulting from higher mobility associated with the initial colonisation period and the later pattern reflecting more sedentary communities.

Neither pattern is like specialist pottery production for exchange seen in the ethnographic past from a number of areas in Papua New Guinea. These differences are represented graphically by comparing Figures 5 and 6 with the representation of specialist production in Figures 7 and 8.

\section{Previous attempts at identifying pot production along the south coast}

This characterisation of Lapita ceramic production allows comparison with south coast EPP production for the first time, but several previous attempts to characterise this latter set are instructive and are briefly reviewed here.

Previous attempts have mainly used physical characterisation analyses. Bill Dickinson, for example, undertook thin section petrographic analysis on selected pot sherds from Nebira 4 sent by Allen (1972:121).

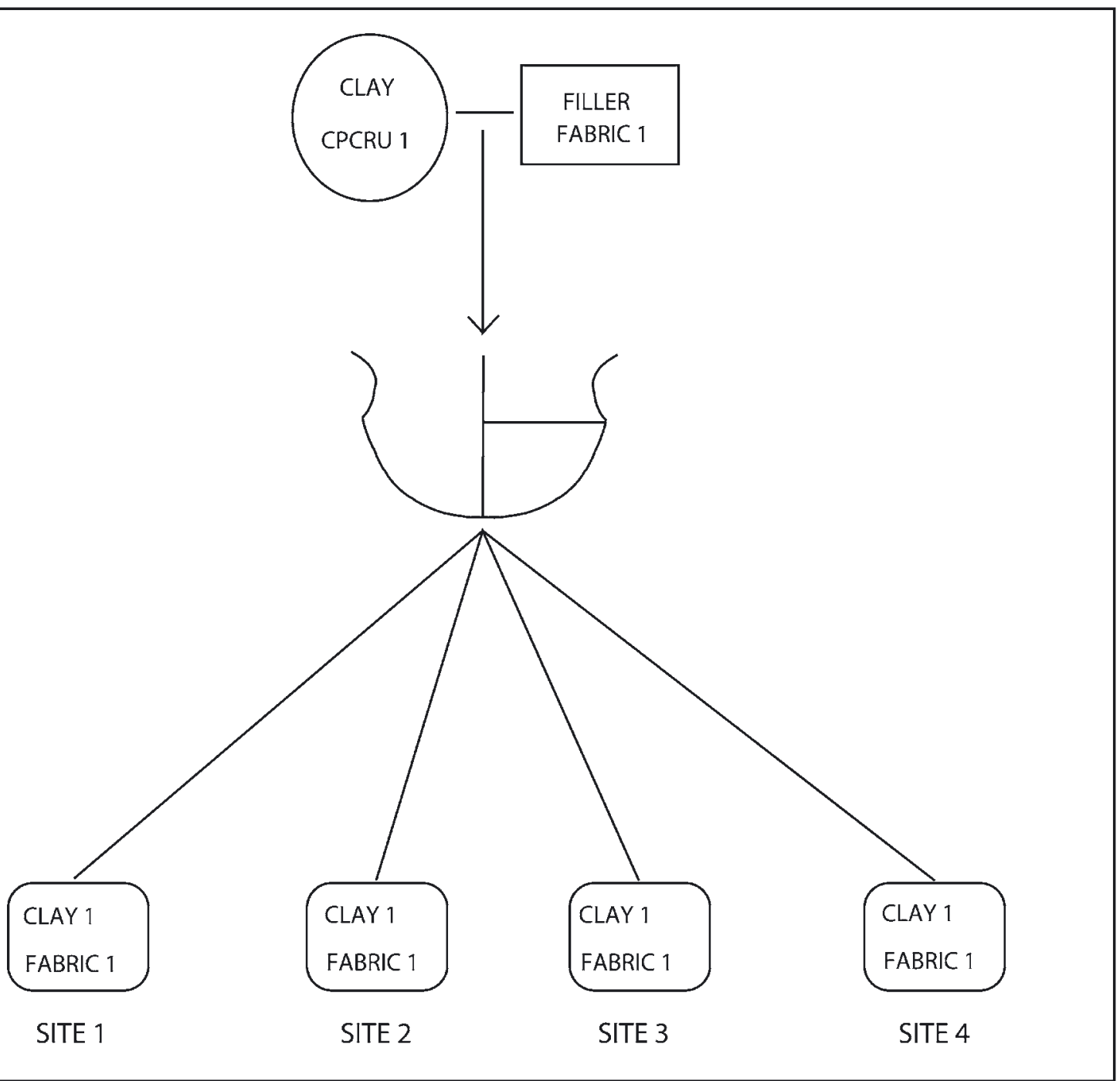

Figure 7. Selection of fabrics from later specialist production, e.g. Motu. 


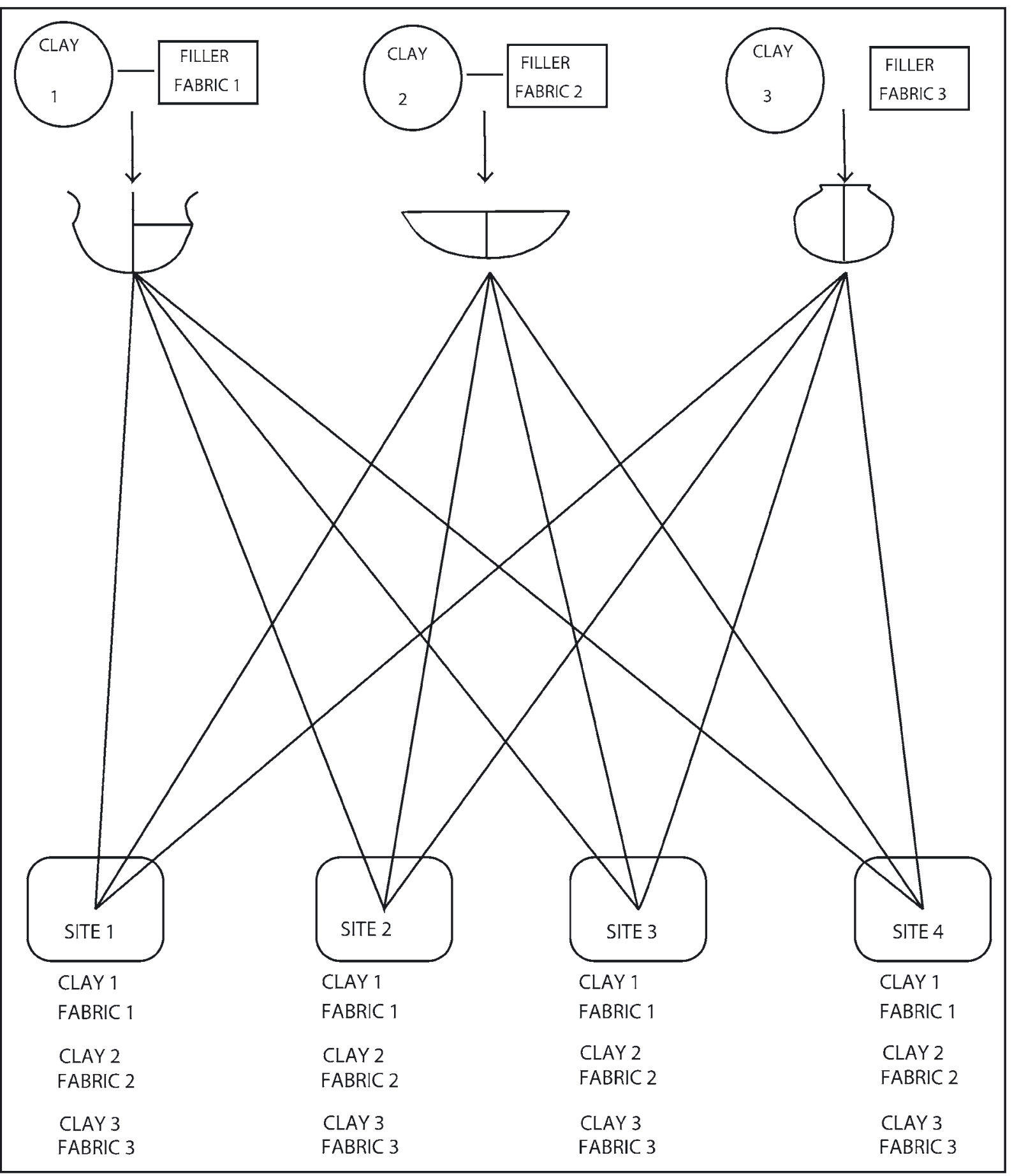

Figure 8. Selection of fabrics expected from a number of operating specialist production centres.

His results led Allen to argue that identically decorated pottery from Oposisi and Nebira 4 was in each case locally made, rather than made in one area and traded out. Allen also noted the presence of misfired pot sherds at both sites, suggesting local production. Allen noting that both sites, although $120 \mathrm{~km}$ apart, shared a similar sequence and must have maintained good communication for over 1,000 years: "cultural contact between sites must have been very close" (Allen 1972:121). 
Geoff Irwin, as part of his doctoral research into Mailu, argued that there was more than one pot manufacturing area during the early period. He based this on the petrographic analysis of 25 samples, and XRF analysis of 139 samples.

Mike Worthing (1980), a geologist at UPNG, attempted to identify production sites by comparing sands collected from selected beaches from the south coast (Boera, Bootless Bay, Moresby Harbour, Papa, Lealea) to sands in pot sherds from Motupore using petrographic analysis. On the basis of Worthing's work, Swadling (1980) argued that very few late EPP pots from Moresby came from the Kairuku area. Swadling, based on Worthing's identification of quartz with mica from his beach sands, also argued that late EPP in the Gulf came from Lealea-Boki area.

Unfortunately Worthing's analysis is limited since, as Bickler (1997) points out, there is little chronological control on the samples such that we cannot determine which samples are early or late. Further, mica and quartz are common to many beaches along the south Papuan Coast and need not be a marker for the Lealea-Boki area alone.

Jim Rhoads as part of his doctoral research had the geologist D. MacKenzie undertake petrographic analysis on EPP potsherds from Kulupuari in the Papuan Gulf. MacKenzie claimed to have sourced the clays (or minerals in them) used to make the pottery to the coastal plain around the Angabunga and Lakekamu rivers, Hall Sound and Motu Motu respectively (Rhoads and Mackenzie 1991:41).

The most recent attempt was by Simon Bickler, then an MA student at the University of Auckland. Pottery from the National Museum and Art Gallery of Papua New Guinea, Port Moresby, was analysed using both petrographic techniques (69 samples) and XRF (128 samples) from 42 EPP sites. Again, Bickler argued that production was mostly local, but with Yule Island area pottery moving to the Gulf during the EPP, and subsequently with Port Moresby pottery taking over at c.1200 BP. The implication here is that Moresby EPP was made locally and not exported.

Other attempts at pottery analysis from the south coast include Thompson (1980), Allen and Rye (1982), Allen and Duerden (1982), Rye (1976,1981), Rye and Allen (1976, 1980), and Rye and Duerden (1982) using different techniques. However these studies were on post-EPP wares and are passed over here.

There are problems with these attempts at identifying production. XRF is not appropriate for analysing coarse pottery, since the technique requires the sample being crushed into a powder. Thus the chemical analysis is a fingerprint of both the ceramic matrix and the inclusions within the fabric. Attempts to characterise production localities is made difficult because of the mineral noise. Thus groupings of production areas based on the chemistry of this analysis may indicate both the variability of the mineral inclusions and combinations of minerals with clays (see Summerhayes 1997 for further explanation). It follows that any comparisons with Lapita pottery production and distribution patterns determined by these studies would be based on faulty data. To redress this problem, we decided to re-analyse new EPP samples.

\section{Detecting production patterns of EPP using the electron microscope}

We employed electron microscopy to provide characterisation data allowing the modelling of production patterns. For this study a sample of 40 sherds were provided by the National Museum and Art Gallery of Papua New Guinea, Port Moresby, from the EPP assemblages of Oposisi, Nebira and Mailu, and analysed using electron microscopy. The electron microscope provides separate chemical analyses of the clay matrix and minerals, rather than the blend of both which most other techniques provide. The reason for this is that the samples are not crushed and a smoothly prepared sample can be moved under the electron beam for spot analysis. The chemical results allow the characterisation of production by grouping sherds on the basis of their chemical similarity into groups called "Chemical Paste Compositional Reference Units" (CPCRU) - see Summerhayes (2000a:Chapter 4) for a detailed description. The samples for chemical analysis consisted of early and later styles of EPP from Oposisi (15 samples), Nebira 4 (15 samples) and Mailu (10 samples). 
Every sherd from the earliest levels of each site was examined using a low powered (x15) microscope, and a relative sample was selected to cover all fabrics and major styles. The fabrics were described using the macro-categories: ferro / magnesium (hornblende, pyroxene), lights (either quartz, feldspars or glass), or shell (calcareous). The selection of samples was not exhaustive, yet was adequate to cover the basic questions of production. Of this sample, two sherds from a late EPP Oposisi level (sample A5 and A6) were included to compare with the earlier EPP material. Table 4 presents a description of the sample, decoration, CPCRU, and fabric from each site.

Pottery was analysed using a scanning electron microscope (JEOL JSM6700F) with an EDS (Energy Dispersive Spectrometer) attachment. Machine conditions used a negative potential of $15 \mathrm{KeV}$ accelerating voltage. Analyses were undertaken at $\times 20,000$ while photos were taken at $\mathrm{x} 100$. Sherd samples were impregnated in epoxy resin pellets. Preparation of sample pellets is identical to those outlined in Summerhayes (2000a), with the exception that slides were not made. Elements analysed were $\mathrm{Na}, \mathrm{Mg}, \mathrm{Al}, \mathrm{Si}, \mathrm{K}, \mathrm{Ca}$, $\mathrm{Ti}, \mathrm{Mn}$ and Fe. Multivariate statistics (Principal Components Analysis and Correspondence Analysis) were used to identify clusters in the chemical analysis and define CPCRUs. A primary aim in the quantitative elemental characterisation of pottery was to define groupings. The groupings were expected to not only make chemical sense, but also archaeological sense.

The macroscopic fabric analysis showed that both Nebira and Oposisi had three fabric groups ( $\mathrm{Fe} / \mathrm{Mg}$, shell and lights), while Mailu only had two (Fe/Mg and shell). The chemical analysis on all samples produced four CPCRUs. One consists of all the Mailu samples (CPCRU I). Two CPCRUs comprise only Nebira 4 samples (CPCRU II and III) but these do not contain all the samples from Nebira 4. The last consists of all Oposisi samples and seven Nebira 4 samples, including all the shell impressed samples and the two grooved lip samples from
Table 4. List of samples for chemical analysis with CPCRU's

\begin{tabular}{|c|c|c|c|}
\hline Sample No. & Notes on decoration & CPCRU & Fabric \\
\hline \multicolumn{4}{|l|}{ OPOSISI } \\
\hline $\mathrm{A} 1$ & shell impressed & I & Light \\
\hline $\mathrm{A} 2$ & incised & I & Light \\
\hline A3 & shell impressed & I & Light \\
\hline A4 & shell impressed & I & Light \\
\hline A5 & incised & I & Shell \\
\hline A6 & incised? (thru red slip) & I & Light \\
\hline A7 & plain rim & I & $\mathrm{Fe} / \mathrm{mg}$ \\
\hline A8 & cut dec lip, incision inside & I & Shell \\
\hline A9 & incised? (thru red slip) & I & Light \\
\hline $\mathrm{A} 10$ & plain rim & I & Light \\
\hline $\mathrm{A} 11$ & plain rim & I & $\mathrm{Fe} / \mathrm{mg}$ \\
\hline $\mathrm{A} 12$ & plain rim, incised inside? & I & $\mathrm{Fe} / \mathrm{mg}$ \\
\hline A13 & None & I & Light \\
\hline A14 & grooved \& incised & I & Light \\
\hline A15 & incised lines & I & Light \\
\hline \multicolumn{4}{|l|}{ MAILU } \\
\hline M1 & shell impressed, notched lip & IV & $\mathrm{Fe} / \mathrm{mg}$ \\
\hline M2 & shell impressed?/incised & IV & $\mathrm{Fe} / \mathrm{mg}$ \\
\hline M3 & incised & IV & $\mathrm{Fe} / \mathrm{mg}$ \\
\hline M4 & impressed? & IV & $\mathrm{Fe} / \mathrm{mg}$ \\
\hline M5 & impressed? & IV & Shell \\
\hline M6 & incised & IV & Shell \\
\hline M7 & plain rim & IV & $\mathrm{Fe} / \mathrm{mg}$ \\
\hline M8 & plain & IV & $\mathrm{Fe} / \mathrm{mg}$ \\
\hline M9 & plain & IV & $\mathrm{Fe} / \mathrm{mg}$ \\
\hline M10 & ?notched & IV & $\mathrm{Fe} / \mathrm{mg}$ \\
\hline \multicolumn{4}{|l|}{ NEBIRA 4} \\
\hline $\mathrm{N} 1$ & linear incised & III & $\mathrm{Fe} / \mathrm{mg}$ \\
\hline N2 & linear incised & I & $\mathrm{Fe} / \mathrm{mg}$ \\
\hline N3 & plain rim & III & Light \\
\hline N4 & plain rim & III & Light \\
\hline N5 & plain rim & II & Light \\
\hline N6 & incised rim - grooved lip & I & Light \\
\hline N7 & $\operatorname{rim}$ & II & Light \\
\hline N8 & rim & III & Light \\
\hline N9 & rim & I & Light \\
\hline N10 & incised lines rim & III & $\mathrm{Fe} / \mathrm{mg}$ \\
\hline N11 & shell impressed & I & $\mathrm{Fe} / \mathrm{mg}$ \\
\hline $\mathrm{N} 12$ & incised? & ॥ & shell \\
\hline N13 & incised and grooved & I & $\mathrm{Fe} / \mathrm{mg}$ \\
\hline N14 & shell impressed & I & Shell \\
\hline N15 & shell impressed & I & Light \\
\hline
\end{tabular}


there (see Table 5 and Figure 9). As previously discussed these sherds comprise the earliest styles at Nebira 4 (Allen 1972:102-8).

In short, most pottery was locally produced at each site, with the important exception of seven samples from Nebira which reflect a similar production to Oposisi and for which the most parsimonious explanation is that the raw materials or much more likely the finished pots came from the Oposisi area. Figure 10 represents the use of fabric (defined macroscopically) with the CPCRUs (defined chemically).

\section{Results of this analysis compared with Lapita patterns}

The results from this limited analysis clearly suggests that pottery production is local during the early part of the EPP and at the same time a number of fabrics are being manufactured with different local clay sources. As with early Lapita, potters are not "conservative" in that they produced similar vessels using different clays and fabrics. Yet, unlike Lapita, there is an indication that some of the earliest EPP wares

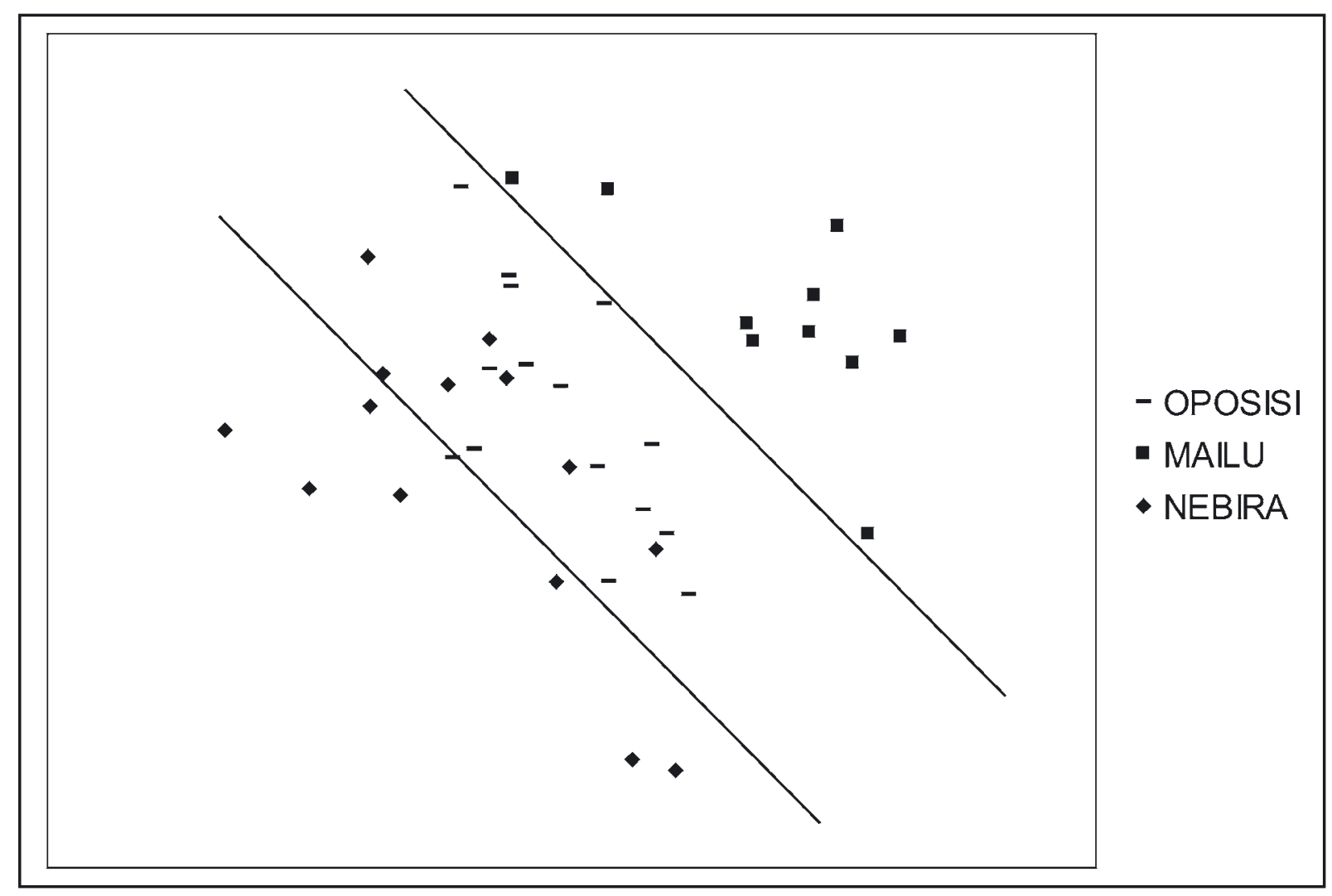

Figure 9. PCA of the pottery analysis.
Table 5. CPCRU's of the South Coast pottery assemblages.

\begin{tabular}{rll}
\hline & Site CPCRU & Site CPCRU \\
\hline I. & OPSISI & NEBIRA SHELL IMPRESSED \\
II. & NEBIRA & \\
III. & NEBIRA & \\
IV. & MAILU & \\
\hline
\end{tabular}




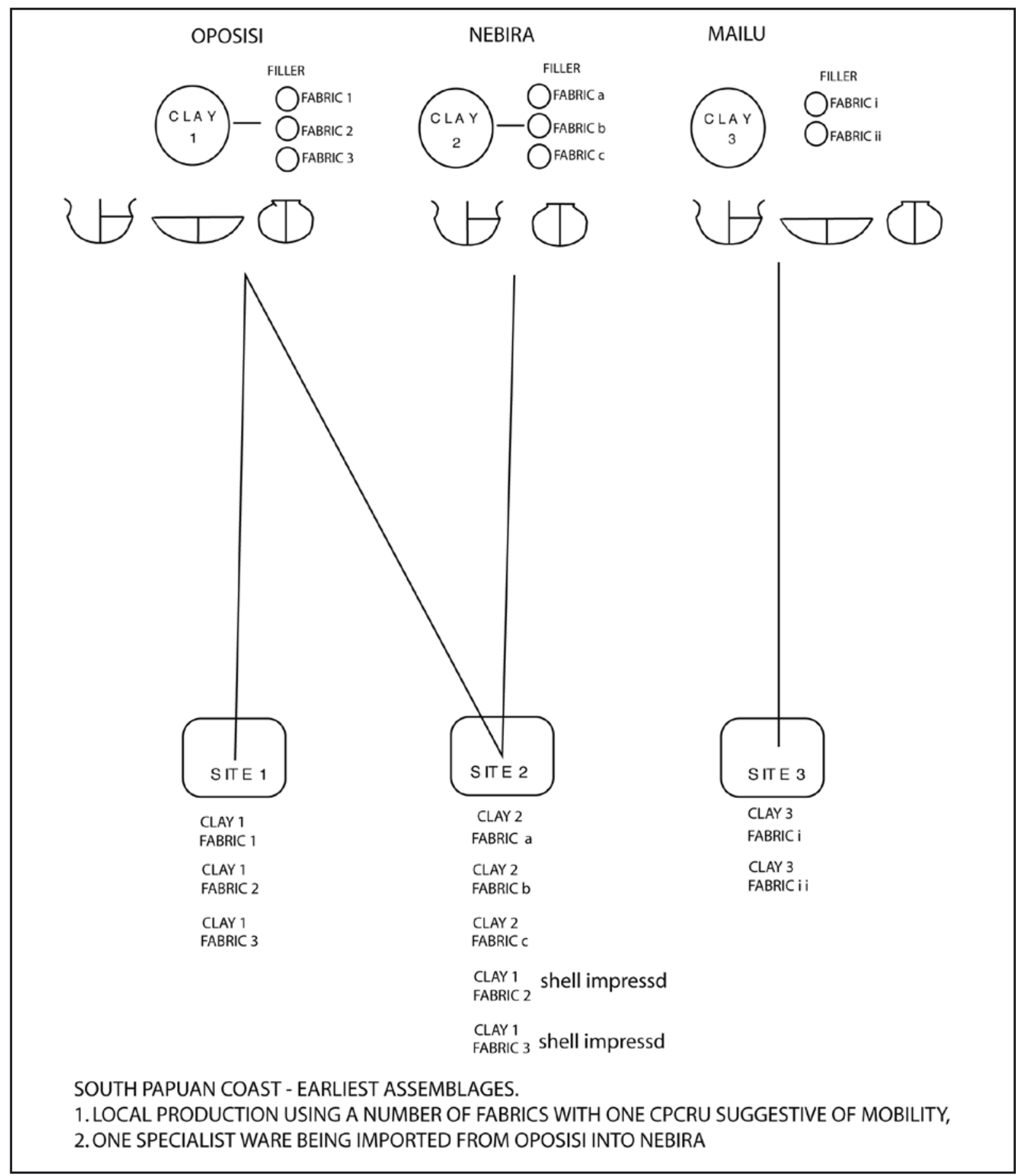

Figure 10. South Coast Pottery Production Pattern.

from Nebira 4 were made in the Oposisi area and taken to Nebira 4. We address this matter further in the discussion.

We would expect this production pattern to change over time as communities become more sedentary. While continuing close connections between EPP groups have been argued on the basis of continuing similarities in general material culture and especially in ceramic forms and decoration, we would still predict that the production patterns of pottery changed, evolving towards the conservative and simple patterns exemplified 
in later Lapita pottery. This is an eminently testable hypothesis that we hope to approach with further analysis of later EPP styles and post-EPP wares from these same areas.

The final point to make is that while these similarities in production between EPP and Lapita are evident in the data, both these signatures remain fundamentally different to the pottery production systems witnessed in Papua New Guinea by Europeans in the nineteenth and early twentieth centuries (Figures 7 and 8).

\section{Discussion}

\section{Comparing the EPP and Lapita colonisations}

It might be legitimately argued that the general similarities between EEP and Lapita in respect of site locations, economies, movements of obsidian, associated non-ceramic materials, and the elaboration of pottery decoration styles, put forward here as similarities in the two colonisations, could equally reflect anticipated similarities between marine communities anywhere in Near Oceania practising a mixed hunter / collector, fishing and horticultural economy. Our argument is rather to suggest that two different rapid colonisations, separated in time and space, both occupying new large territories, did not differ in these general characteristics. These provide the background for more specific characterisations that do relate more directly to the similarities of these colonisations.

\section{Pottery production systems and their implications}

Our data show that the pottery production systems associated with these colonisations were not conservative and probably differed from pottery production systems in the homelands of the colonising groups. They reveal local experimentation using different combinations of clays and fillers to make culturally similar pots, in terms of forms and decoration styles, across wide distances. In the case of later Lapita ceramics we know that production techniques simplified towards a single clay and single filler in any local area, and although we are yet to demonstrate it we would hypothesise the same is true for EPP. At the same time these early production techniques in both cases are different from those associated with later specialised trading communities in Melanesia.

As an observation, technological experimentation amongst colonising potting communities is not unexpected to the point of being predictable. However it signals in the archaeological record the expectation that a range of other technologies not preserved in that record, from canoes and fishing technologies to terrestrial subsistence patterns must also have undergone experimentation and adaptation. This in turn focusses on risk and risk minimisation in the colonising process, exemplified in those archaeological indicators that reflect connectedness between colonies and back to putative homelands, such as obsidian and ceramic decorative styles.

\section{Modelling colonisation}

In another context one of us (JA) together with Jim O'Connell (University of Utah) is currently modelling the initial colonisation of Australia and New Guinea some 45,000 years ago. In considering continents devoid of previous humans we favour the Ideal Free Distribution (IFD) model developed by Fretwell (1972:83 and ff.). This model suggests that the way individuals occupy new territories is set up via habitat selection. The model suggests that in an empty landscape the "best" habitats, that is, those that optimise evolutionary success, will be occupied first. These "best" habitats we call sweet spots. As well as offering the best avenues to subsistence, sweet spots will have other advantages ranging from good defences against predators (human or non-human), to the availability of required raw materials, to open lines of 
communication with other related groups of colonists in order to ensure longer term biological success, a difficult task for small groups of isolated colonists. Sweet spots diminish in suitability as populations within them increase, at which time new sweet spots further afield may be sought or less sweet spots behind the line of colonisation, by-passed in the first onwards movement, may be subsequently occupied. If the colonists are fishing/hunting horticulturalists, a variation on this model might see initial "beach head" colonies expanding locally to occupy other valuable niches.

Although we would not push the case too far we see that Nebira 4, an outlier in a locational sense among EPP sites, might have been particularly dependent on a parent colony in the Oposisi area, thus making sense of the Oposisi fabrics identified in the early EPP wares at Nebira 4.

How this model applies in occupied landscapes (as is the case with EPP and Lapita in Near Oceania), is less certain. While some locations such as small offshore islands may have been little used by non-pottery using hunter-gatherers, other parts of the coastline and inland are assumed to have been occupied before these colonisations, and valuable resources such as New Britain obsidian would likely have been controlled by incumbent groups. The IFD model assumes that new arrivals are free to settle where they want and the model loses coherence when this assumption is not met. A possible archaeological signature reflecting the colonising of occupied lands is discussed in the next section.

\section{The elaboration of material culture by colonising groups}

A striking feature of both colonisations is an initial elaborate material culture that becomes less elaborated through time. This decline is particularly rapid in the case of EPP. It has sometimes been argued that the early elaborate material is a reflection of the homeland culture, and at some level it must be - no group can invent a new and elaborate material culture instantaneously and in vacuo. But the fact that these 'homeland cultures' remain elusive demonstrates that this explanation is at best only a partial one. In the case of Lapita there has been a long and fruitless search for immediate antecedents for highly elaborate dentate stamped pottery west of the Bismarcks, nor can we point to antecedents of the initial highly decorated shell impressed wares of the EPP beyond the Massim.

The evident conclusion in both instances is that pottery decoration is elaborated internally as part of the colonising process.

In seeking an explanation for this we have been drawn to "costly signalling", a theory of behavioural ecology applied to human and non-human organisms that has developed from Veblen (1994[1899]) and Mauss (1969[1925]) and has had a recent resurgence as an explanatory tool in anthropology (Bliege Bird and Smith 2005 plus comments and references). For present purposes we can define costly signalling as expensive displays designed to show the signaller's worth to observing predators and competitors. In two papers on turtle hunting in Torres Strait, Smith and Bliege Bird (2000) and Smith et al. (2003) propose that costly signalling must be observable by others, be beneficial to others, be truthful, must demonstrate some strength or fitness of the signaller and must be costly to the signaller in ways that cannot be directly reciprocated. Thus, altruistic acts, while costly, establish reputation that encourages others to engage in reciprocal altruism.

We see two immediate applications of this theory to the colonisations described here. The elaboration of pottery decoration and the bone and shell components of the earliest phases of both the EPP and Lapita can be seen to have two roles within the framework of costly signalling as just described.

The first is in relationships between colonisers and incumbent groups. Although they may have superior technology it is in the best long term interests of colonists to avoid conflict with incumbent groups when, by the very nature of the colonising act, the newcomers will inevitably compete for land and resources with existing groups. By elaborating their material culture the colonists signal their own strength or fitness and provide objects that by exchange will confer prestige or other more utilitarian values on the recipients. Exchanges of colonisers' artefacts for hunted food and raw materials would facilitate the success of a new 
settlement both directly and by promoting peaceful relationships. Alternatively if colonists could access wives from local incumbent groups they could improve their likelihood of biological success and again promote peaceful relationships. As the colonisers became established the levels of costly signalling would become less immediately necessary and would predictably diminish, but should never completely disappear.

The second use of costly signalling should be between different colonising villages to maintain access to resources not available locally and also to marriage partners. If women were potters, well-made, elaborately decorated pots could signal the fitness of marriage partners. This model makes sense of movement of pots (and their contents) between villages that all most likely made pottery. We have already seen in our sourcing results this process on the Papuan coast, in respect of Oposisi area pots appearing in the early levels of Nebira 4, even though pots were also being made at this latter site; for Lapita, Kirch (2000:113) notes that during its earliest phase the Mussau site of Talepakemalai received a significant range of outside materials, including obsidian, basalt and andesite rocks, chert, metavolcanic adzes and pottery, "especially decorated vessels", from at least 12 different localities / clay sources thought to include Manus, New Ireland and New Ireland's offshore islands. While these were likely traded against a range of locally made shell valuables, under the model we would anticipate that decorated pots might also move out of Mussau.

On the central Papuan coast this internal reciprocity continues throughout the EPP phase at least between sites in the Port Moresby and Yule Island areas. Although the most elaborate shell impressed decoration disappears quickly the subsequent EPP bowls in particular are still well-decorated, especially when compared to the most recent millennium. It may be telling that the percentage of decorated bowls at Nebira 4 rarely falls below $50 \%$ until the end of the sequence.

In conclusion this proposal offers an alternative explanation for the initial phase of elaborate dentate stamping in the early period of Lapita (see also Clark this volume). It is an idea that has sprung directly from a comparison of two different but similar colonisations as we have been urged to do by Irwin. Its explanatory power seems difficult but perhaps not impossible to test in the EPP case, but seems to have a straightforward test that might be applied in the case of Lapita, since that colonisation occurred firstly in the previously occupied lands of Near Oceania and very soon after in the unoccupied islands of Remote Oceania. A detailed review of highly decorated wares in the early sites of each main island group on either side of this divide, in terms of their nature, the lengths of time they endured and their frequency within the wider Lapita ceramic repertoire, could illuminate this question. If this model has any usefulness we would predict that the frequency of elaborate decoration would be lower and its loss quicker in Remote Oceania compared with Near Oceania.

\section{Acknowledgements}

We would like to thank the National Museum and Art Gallery of Papua New Guinea for the loan of and permission to analyse the pottery from Oposisi, Nebira and Mailu. In particular thanks to Mr Herman Mandui for facilitating the loan. We acknowledge and thank the support of the National Research Institute of Papua New Guinea, and the help of Mr Jim Robins. Special thanks to Amy Findlater, Otago University, for help with the electron microprobe analysis of the pottery. Thanks also to Lorraine Patterson and the Department of Geology, Otago University, for their support in this work. 


\section{References}

Allen, J. 1972. Nebira 4: An early Austronesian site in Central Papua. Archaeology and Physical Anthropology in Oceania 7:92-124.

Allen, J. 1977a. Fishing for wallabies: trade as a mechanism for social interaction, integration and elaboration on the Central Papuan coast. In J. Friedman and M. Rowlands (eds), The Evolution of Social Systems, pp. 419-455. London: Duckworth.

Allen, J.1977b. Management of resources in prehistoric coastal Papua. In J.H. Winslow (ed.), The Melanesian Environment, pp. 35-44. Canberra: ANU Press.

Allen, J. 2000. From beach to beach: the development of maritime economies in prehistoric Melanesia. In S. O'Connor and P. Veth (eds), East of Wallace's Line; Studies of Past and Present Maritime Cultures of the Indo-Pacific Region, pp. 139-177. Published as Modern Quaternary Research in SE Asia 16. Rotterdam: A. A. Balkema.

Allen, J. and P. Duerden 1982. Progressive results from the PIXE program for sourcing prehistoric Papuan pottery. In W. Ambrose and P. Duerden (eds), Archaeometry: An Australasian Perspective, pp.45-49. Canberra: Department of Prehistory, RSPAS, Australian National University, Occasional Papers in Prehistory 12.

Allen, J. and O. Rye 1982. The importance of being earnest in archaeological investigations of prehistoric trade in Papua. In T. Dutton (ed.), The Hiri in History, pp.99-116. Canberra: Australian National University, Pacific Research Monograph 8.

Ambrose, W. 1976. Obsidian and its prehistoric distribution in Melanesia. In N. Barnard (ed.), Ancient Chinese Bronzes and Southeast Asian Metal and other Archaeological Artefacts, pp. 351-78. Melbourne: National Gallery of Victoria.

Ambrose, W. 1978. The loneliness of the long distance trader in Melanesia. Mankind 11:326-333.

Anderson, A., S. Bedford, G. Clark, I. Lilley, C. Sand, G. Summerhayes and R. Torrence 2001. An inventory of Lapita sites containing dentate-stamped pottery. In G.R. Clark, A.J. Anderson and T. Vunidilo (eds), The archaeology of Lapita dispersal in Oceania, pp. 1-14. Canberra: Pandanus Books, Terra Australis 17.

Best, S. 1987. Long distance obsidian travel and possible implications for the settlement of Fiji. Archaeology in Oceania 22:31-32.

Bickler, S. H. 1997. Early pottery exchange along the south coast of Papua New Guinea. Archaeology in Oceania 32:151-162.

Bickler, S. 1999a. Characterisation without sources: Early Prehistoric pottery from the South Coast of New Guinea. In J-C Galipaud and I. Lilley (eds), The Western Pacific from 5000 to 2000 BP. Colonisation and transformations, pp.461-475. Paris: IRD editions.

Bickler, S.H. 1999b. Secondary Burial Practices in the Northern Kula Ring. In M. Boyd, J.C. Erwin and M. Hendrickson (eds), The Entangled Past: Integrating History and Archaeology, pp.98-107. Calgary: University of Calgary.

Bickler. S.H. 2006. Prehistoric stone monuments in the northern region of the Kula ring. Antiquity 80:38-51.

Bickler, S.H., B. Ivuyo and V. Kewibu 1997. Archaeology at the Suloga Stone Tool Manufacturing Sites, Woodlark Island, Milne Bay Province, PNG. Archaeology in New Zealand 40: 204-219.

Bird, J.R., W.R. Ambrose, L.H. Russell and M.D. Scott 1981. The characterisation of Melanesian obsidian sources and artefacts using proton induced gamma-ray (PIGME) emission technique. AAEC/E510. Lucas Heights: Australian Atomic Energy Commission.

Bliege Bird, R. and E.A. Smith 2005. Signalling theory, strategic interaction, and symbolic capital. Current Anthropology 46:221-248.

Bulmer, S. 1971. Prehistoric settlement patterns and pottery in the Port Moresby area. Journal of Papua New Guinea Society 5:28-91. 
Bulmer, S. 1978. Prehistoric change in the Port Moresby Region. Unpublished PhD thesis. University of Papua New Guinea.

Bulmer, S. 1979. Prehistoric ecology and economy in the Port Moresby region. New Zealand Journal of Archaeology $1: 5-27$.

Bulmer, S. 1999. Revisiting red slip: the Laloki style pottery of Southern Papua and its possible relationship to Lapita. In J-C. Galipaud and I. Lilley (eds), The Western Pacific from 5000 to 2000 BP. Colonisation and transformations, pp. 543-577. Paris: IRD editions.

Burenhult, G. (ed.) 2002. The Archaeology of the Trobriand Islands, Milne Bay Province, Papua New Guinea. Excavation Season 1999. Oxford: BAR International Series 1080.

Butler, V.L. 1988. Lapita fishing strategies. In P.V. Kirch and T.L. Hunt (eds), Archaeology of the Lapita Cultural Complex: A Critical Review, pp. 9-31. Seattle: Burke Museum. Thomas Burke Memorial Washington State Museum Research Report No. 5.

Crowther, A. 2005. Starch residues on undecorated Lapita pottery from Anir, New Ireland. Archaeology in Oceania 40: 62-66.

Egloff, B. 1971a. Collingwood Bay and the Trobriand Islands in recent prehistory: Settlement and interaction in coastal and Island Papua. Unpublished PhD thesis, Australian National University, Canberra.

Egloff, B. 1971b. Archaeological research in the Collingwood Bay area of Papua. Asian Perspectives 14:60-64.

Egloff, B. 1978. The Kula before Malinowski: A changing configuration. Mankind 11(3) 429-35.

Egloff, B. 1979. Recent Prehistory in Southeast Papua. Canberra: Department of Prehistory, Australian National University, Terra Australis 4.

Frankel, D. and J.W. Rhoads 1994. Archaeology of a coastal exchange system: Sites and Ceramics of the Papuan Gulf. Canberra: Australian National University, Research Papers in Archaeology and Natural History No. 25.

Frankel, D. and R. Vanderwal 1982a. Archaeological investigations near Kerema, Gulf Province, Papua New Guinea 1980-81: Preliminary field report. Research in Melanesia 6:20-32.

Frankel, D. and R. Vanderwal, R. 1982b. Prehistoric research at Kinomere Village, Papua New Guinea, 1981: Preliminary field report. Australian Archaeology 14:86-95.

Frankel, D. and Vanderwal, R. 1985. Prehistoric research in Papua New Guinea. Antiquity 59:113-15.

Fretwell, S. D. 1972. Populations in a Seasonal Environment. Princeton New Jersey: Princeton University Press.

Green, R.C. 1987. Obsidian results from the Lapita sites of the Reef/Santa Cruz Islands. In W.R. Ambrose and J.M. Mummery (eds), Archaeometry: Further Australasian Studies, pp.239-249. Canberra: RSPAS, Australian National University. Occasional Papers in Prehistory 14.

Green, R.C. and D. Anson 2000. Excavations at Kainapirina (SAC), Watom Island, Papua New Guinea. New Zealand Journal of Archaeology 20 (1998): 29-94.

Green, R.C. and J.R Bird 1989. Fergusson Island obsidian from the D'Entrecasteauz Group in a Lapita site of the Reef Santa Cruz Group. New Zealand Journal of Archaeology 11: 87-99.

Hanslip, M. 2001. Expedient technologies? Obsidian artefacts in Island Melanesia. Canberra. Unpublished PhD thesis, Australian National University.

Horrocks, M. and S. Bedford 2005. Microfossil analysis of Lapita deposits in Vanuatu reveals introduced Araceae (aroids). Archaeology in Oceania 40:67-74.

Horrocks, M. and Nunn, P.D. 2007. Evidence for introduced taro (Colocasia esculenta) and lesser yam (Dioscorea esculenta) in Lapita-era (c.3050-2500 cal. Yr BP) deposits from Bourewa, southwest Viti Levu Island, Fiji. Journal of Archaeological Science 34:739-748.

Irwin, G. 1977. The emergence of Mailu as a central place in the prehistory of coastal Papua. Unpublished PhD thesis, Australian National University.

Irwin, G. 1978a. Pots and entrepots. World Archaeology 9:299-319. 
Irwin, G. 1978b. The development of Mailu as a specialised trading and manufacturing centre in Papuan prehistory: The causes and implications. Mankind 11:406-415.

Irwin, G. 1983. Chieftainship, kula, and trade in Massim Prehistory. In J.W. Leach and E. Leach (eds), The Kula: New Perspectives on Massim Exchange, pp. 29-72. Cambridge: Cambridge University Press.

Irwin, G. 1985. The Emergence of Mailu. Canberra: Department of Prehistory, Australian National University. Terra Australis 10.

Irwin, G. 1991. Themes in the prehistory of Coastal Papua and the Massim. In A. Pawley (ed.) Man and a Half: Essays in Pacific anthropology and ethnobiology in honour of Ralph Bulmer, pp.503-510. Auckland: Polynesian Society.

Irwin, G. and S. Holdaway 1996. Colonisation, trade and exchange: From Papua to Lapita. In J. Davidson, G. Irwin, F. Leach, A.Pawley and D. Brown (eds), Oceanic Culture History: Essays in Honour of Roger Green, pp. 22535. Dunedin: New Zealand Journal of Archaeology Special Publication.

Kirch, P.V. 1988. Long-distance exchange and island colonization: the Lapita case. Norwegian Archaeological Review 21:103-117.

Kirch, P.V. 1989. Second millennium B.C. arboriculture in Melanesia: Archaeological evidence from the Mussau Islands. Economic Botany 43: 225-40.

Kirch, P.V. 2000. On the Road of the Winds: An Archaeological History of the Pacific Islands before European Contact. Berkeley: University of California Press.

Kirch, P.V. and D.E.Yen 1982. Tikopia: The Prehistory and Ecology of a Polynesian outlier. Honolulu: Bishop Museum Press, Bishop Museum Bulletin 238.

Kirch, P.V., Hunt, T.L, Weisler, M., Butler, V. and Allen, M.S. 1991. Mussau Islands prehistory: results of the 1985-86 excavations, in Allen, J. and Gosden, C. (eds), Report of the Lapita Homeland Project, pp.144-163. Canberra: Department of Prehistory, Australian National University, Occasional Papers in Prehistory 20.

Kewibu, V. pers. comm. PhD candidate, Department of Archaeology and Natural History, Australian National University.

Lauer, P. 1970. Amphlett Islands pottery trade to the Trobriand Islands. Mankind 7:165-76.

Lauer, P. 1971. Changing patterns of pottery trade to the Trobriand Islands. World Archaeology 3:197-209.

Lauer, P. 1974. Pottery traditions in the d'Entrecasteaux Islands of Papua. Brisbane: University of Queensland Press. Occasional Papers in Anthropology 3.

Leach, B.F., C.J. Quinn, G.L. Lyon, A. Haystead and D.B. Myers 2000. Evidence of Prehistoric Lapita Diet at Watom Island, Papua New Guinea, using Stable Isotopes. Journal of New Zealand Archaeology (1998) 20:149-159.

Lentfer, C.J. and R. Green 2004. Phytoliths and the evidence for banana cultivation at the Lapita Reber-Rakival Site on Watom Island, Papua New Guinea. Records of the Australian Museum Supplement 29: 75-88.

Mauss, M. 1969(1925). The Gift. Forms and Functions of Exchange in Archaic Societies. London: Cohen and West Ltd.

Mc Niven, I., W.R. Dickinson, B. David, M. Weisler, F. von Gnielinski, M. Carter and U. Zoppi 2006. Mask cave: Red-slipped pottery and the Australian-Papuan settlement of Zenadh Kes (Torres Strait). Archaeology in Oceania 41: 49-81.

Matthews, P. J. and C. Gosden 1997. Plant remains from waterlogged sites in the Arawe Islands, West New Britain Province, Papua New Guinea: Implications for the history of plant use and domestication. Economic Botany 51:121-133.

Pawley, A. 1969. Notes on the Austronesian Languages of Central Papua. Mimeo., Department of Anthropology and Sociology, U.P.N.G.

Rhoads, J. 1980. Through a Glass Darkly: Present and past land-use systems of Papuan Sagopalm users. Unpublished PhD thesis, Australian National University.

Rhoads, J. 1982. Prehistoric Papuan Exchange Systems: The Hiri and its Antecedents. In T. Dutton, (ed.), The Hiri in History. Further Aspects of Long Distance Motu Trade in Central Papua, pp.131-150. Pacific Resource Monograph 8. Canberra: Australian National University. 
Rhoads, J. and D. Mackenzie 1991. Stone axe trade in prehistoric Papua: The travels of the Python. Proceedings of the Prehistoric Society 57:35-49.

Rye, O. 1976. Keeping your temper under control. Archaeology and Physical Anthropology in Oceania 11:106-137.

Rye, O. 1981. Pottery Technology: Principles and Reconstruction. Washington: Taraxacum.

Rye, O. and J. Allen 1976. New approaches to Papuan pottery analysis. In J. Garanger (ed.), Colloque XXII, La Préhistoire Océanienne, Prétirage, pp.198-222. Nice: IXe Congrés, Union Internationale des Sciences Préhistoriques et Protohistoriques.

Rye, O. and J. Allen 1980. New approaches to Papuan pottery analysis. Journal de la Société des Océanistes 69:305-314.

Rye, O. and P. Duerden 1982. Papuan pottery sourcing by PIXE: Preliminary studies. Archaeometry 24:59-64.

Smith, I. 2000. Terrestrial fauna from excavations at the Kainapirina (SAC) locality, Watom Island, Papua New Guinea. New Zealand Journal of Archaeology 20:137-147.

Smith, E. A. and R. Bliege Bird 2000. Turtle hunting and tombstone opening. Public generosity as costly signalling. Evolution and Human Behaviour 21:245-261.

Smith, E. A., R. Bliege Bird and D.W. Bird 2003. The benefits of costly signalling: Meriam turtle hunters. Behavioural Ecology 14:116-26

Specht, J. 2002. Obsidian, colonising and exchange. In S. Bedford, C. Sand and D. Burley (eds), Fifty years in the field. Essays in Honour and celebration of Richard Shutler Jr's Archaeological Career, pp.37-49. Auckland: New Zealand Archaeological Association Monograph 25.

Specht, J. 2005. Revisiting the Bismarcks: some alternative views. In A. Pawley, R. Attenborough, J. Golson and R. Hide (eds), Papuan Pasts: cultural, linguistic and biological histories of Papuan-speaking peoples, pp.235-288. Canberra: Pacific Linguistics 572, Australian National University.

Summerhayes, G.R. 1997. Losing your temper: the effect of mineral inclusion on pottery analysis. Archaeology in Oceania 32:108-118

Summerhayes, G.R. 2000a. Lapita Interaction. Canberra: Centre of Archaeological Research, Australian National University. Terra Australis No.15

Summerhayes, G.R. 2000b. Far Western, Western and Eastern Lapita - A re-evaluation. Asian Perspectives 39:109-138.

Summerhayes, G.R. 2003. Modelling differences between Lapita obsidian and pottery distribution patterns in the Bismarck Archipelago. In C. Sand (ed.), Pacific Archaeology: assessments and prospects. Proceedings of the International Conference for the 50th anniversary of the first Lapita excavation (July 1952), Koné-Nouméa, pp. 139-149. Nouméa: Les Cahiers de l'Archéologie en Nouvelle-Calédonie 15.

Summerhayes, G.R. 2004. The nature of prehistoric obsidian importation to Anir and the development of a 3,000 year old regional picture of obsidian exchange within the Bismarck Archipelago, Papua New Guinea. In V.J. Attenbrow and R. Fullagar (eds), Archaeologist and Anthropologist in the Western Pacific: Essays in Honour of Jim Specht, pp. 245-156. Sydney: Records of the Australian Museum Supplement 29.

Summerhayes, G.R. In press (a). The rise and transformation of Lapita in the Bismarck Archipelago. In S. Chui and C. Sand (eds), From southeast Asia to the Pacific: Archaeological perspectives on the Austronesian expansion and the Lapita Cultural Complex. Taipei: Academia Sinica.

Summerhayes, G.R. In press (b). Melanesian Obsidian - Its Sources, Characterisation and Distribution. In M. Suzuki, W. Ambrose and G.R. Summerhayes (eds), Proceedings of the International Obsidian Summit, Tokyo 2004. Tokyo: Rikkyo University.

Swadling, P. 1977. A review of the traditional and archaeological evidence for early Motu, Koita and Koiari settlement along the Central South Papuan Coast. Oral History V: 37-57.

Swadling, P. 1980. Decorative features and sources of selected potsherds from archaeological sites in the Gulf and Central Province. Oral History VIII:101-123. 
Swadling, P. 1981. The settlement history of the Motu and Koita speaking people of the Central Province, Papua New Guinea. In D. Denoon, D. and R. Lacey (eds), Oral Tradition in Melanesia, pp. 241-251. Port Moresby: University of PNG and the Institute of Papua New Guinea Studies.

Swadling, P. (n.d.). Was there a hiatus in human settlement 1,000 years ago in the Port Moresby Area? Unpublished manuscript.

Swadling, P. and O. Kaiku 1980. Radiocarbon date from a fireplace in the clay surface of an eroded village site in the Papa salt pans, Central Province. Oral History VIII P. 86.

Swadling, P., L. Aitsi, G. Trompf and M. Kari 1976. Beyond the early oral traditions of the Austronesian speaking people of the Gulf and Western Central Provinces: a speculative appraisal of early settlement in the Kairuku District. Oral History V:50-80.

Szabo, K. and Summerhayes, G. 2002. Worked Shell Artefacts - New Data from Early Lapita. In S. Bedford, C. Sand and D. Burley (eds), Fifty Years in the Field. Essays in Honour and Celebration of Richard Shutler's Archaeological Career, pp. 91-100. Auckland: New Zealand Archaeological Association Monograph 25.

Terrell, J.E. and R.L. Welsch 1997. Lapita and the temporal geography of prehistory. Antiquity 71:548-572.

Thompson, K. 1982. Beyond Description: A compilation and explanation of pottery from six archaeological sites in the Gulf Province, Papua New Guinea. Unpublished BA (Hons) thesis. La Trobe University, Melbourne.

Torrence, R., V. Neall, T. Doelman, E. Rhodes, C. McKee, H. Davies, R. Bonetti, A. Gugliemetti, A. Manzoni, M. Oddone, J. Parr, and C. Wallace 2004. Pleistocene colonisation of the Bismarck Archipelago: new evidence from West New Britain. Archaeology in Oceania 39: 101-130.

Vanderwal, R. L. 1973. Prehistoric Studies in the Central Coast Papua. Unpublished PhD Thesis. Australian National University, Canberra.

Vanderwal, R. 1978. Exchange in Prehistoric Coastal Papua. Mankind 11:416-28.

Veblen, T. 1994(1899). The Theory of the Leisure Class. Dover, New York.

White, J.P. 1965. An archaeological survey in Papua New Guinea. Current Anthropology 6:334-335.

White, J.P. with O'Connell, F. 1982. A Prehistory of Australia, New Guinea and Sahul. Sydney: Academic Press.

White, J.P., H. Jacobsen, V. Kewibu and T. Doelman 2006. Obsidian traffic in the southeast Papuan Islands. Journal of Island and Coastal Archaeology 1: 101-108.

Worthing, M.A. 1980. South Papuan Coastal sources of potsherds from the Gulf area of PNG. Oral History VIII: 87-100. 